\title{
Efficacy of CDK4 inhibition against sarcomas depends on their levels of CDK4 and p16ink4 mRNA
}

\author{
Marco Perez ${ }^{1}$, Sandra Muñoz-Galván ${ }^{1}$, Manuel P. Jiménez-García ${ }^{1}$, Juan J. Marín ${ }^{1,2}$, \\ Amancio Carnero ${ }^{1}$ \\ ${ }^{1}$ Instituto de Biomedicina de Sevilla, IBIS/Hospital Universitario Virgen del Rocio/ Universidad de Sevilla/Consejo Superior \\ de Investigaciones Cientificas, Seville, Spain \\ ${ }^{2}$ Department of Public Health and Preventive Medicine, University of Seville, Seville, Spain
}

Correspondence to:

Amancio Carnero, e-mail: acarnero-ibis@us.es

Keywords: cell cycle, CDKs, cyclin dependent kinase inhibitor, sarcomas, cellular senescence

Received: July 13, 2015

Accepted: September 24, 2015

Published: October 20, 2015

\section{ABSTRACT}

Sarcomas are malignant tumors accounting for a high percentage of cancer morbidity and mortality in children and young adults. Surgery and radiation therapy are the accepted treatments for most sarcomas; however, patients with metastatic disease are treated with systemic chemotherapy. Many tumors display marginal levels of chemoresponsiveness and new treatment approaches are needed. Deregulation of the $\mathbf{G 1}$ checkpoint is crucial for various oncogenic transformation processes, suggesting that many cancer cell types depend on CDK4/6 activity. Thus, CDK4/6 activity appears to represent a promising therapeutic target for cancer treatment. In the present work, we explore the efficacy of CDK4 inhibition using palbociclib (PD0332991), a highly selective inhibitor of CDK4/6, in a panel of sarcoma cell lines and sarcoma tumor xenografts (PDXs). Palbociclib induces senescence in these cell lines and the responsiveness of these cell lines correlated with their levels of CDK4 mRNA. Palbociclib is also active in vivo against sarcomas displaying high levels of CDK4 but not against sarcomas displaying low levels of CDK4 and high levels of p16ink4a. The analysis of tumors growing after palbociclib showed a clear decrease in the CDK4 levels, indicating that clonal selection occurred in these treated tumors. In summary, our data support the efficacy of CDK4 inhibitors against sarcomas displaying increased CDK4 levels, particularly fibrosarcomas and MPNST. Our results also suggest that high levels of p16 ink4a may indicate poor efficacy of CDK4 inhibitors.

\section{INTRODUCTION}

Sarcomas are malignant tumors derived from the mesenchymal nonepithelial tissue developed from the embryonic mesoderm [1], comprising less than $10 \%$ of all cancers [2,3] but account for a higher percentage of overall cancer morbidity and mortality in children and young adults than in adults. The overwhelming majority of sarcomas are sporadic with unknown etiology, but several well-described genetically linked cancer predisposition syndromes and well-documented types of environmental exposure have been associated with specific types of sarcoma $[2,3]$. Sarcomas arise from multiple lineages and range from indolent to highly invasive and metastatic $[4,5]$. Taxonomical analysis of sarcomas has identified approximately 60 subtypes of sarcoma, as well as more than 50 benign tumor subtypes [4]. Sarcomas are usually grouped in two broad categories according to molecular genetics: sarcomas harboring a diploid or nearly diploid karyotype and simple genetic driver alterations, such as Ewing's sarcoma, or sarcomas with a complex and imbalanced karyotype, such as osteosarcoma. Both subgroups include very different clinical entities and are broadly drawn, not reflecting the genetic diversity among tumors of a given type or subtype or their diverse tumor biology [4].

Surgery is the accepted treatment for most sarcomas. However, for those patients with unresectable disease or residual tumors following surgery, radiation therapy is also used. Patients with metastatic disease are treated with systemic chemotherapy, usually consisting of doxorubicin and ifosfamide [6]. This approach has been demonstrated 
to be effective in patients who have localized tumors, and the long-term survival rates of such patients are increasing [6]. However, for many tumors that exhibit marginal levels of chemoresponsiveness and for metastatic disease, new treatment approaches are needed. Treatments for sarcomas include doxorubicin, gemcitabine, ifosfamide and the recently accepted drug trabectedin [7-10]. Currently, few specific genetic alterations in sarcomas are direct targets for therapy, in contrast to the circumstance for epithelial cancers. The exceptions are GISTs, in which the Kit kinase inhibitor imatinib induces a partial response or stable disease in approximately $80 \%$ of sarcoma patients [4]. Those findings support the hypothesis that widely diverse sarcoma tumors may share a dependence on a particular kinase and that inhibiting this kinase may, therefore, be expected to be effective for all histological subtypes that are positive for this biomarker.

Aberrant regulation of the cell cycle is a hallmark of cancer, and multiple mechanisms contribute to the deregulation of the G1-to-S checkpoint $[11,12]$. These mechanisms include amplification or mutation of the CDK4 and CDK6 genes, amplification of the genes encoding D-type cyclins and deletion or silencing of the $C D K N 2 A / B$ gene, which encodes for the INK4 inhibitors $\mathrm{p} 16^{\text {ink4a }}$ and $\mathrm{p} 15^{\text {ink4b }}$ [13-15]. Additionally, the aberrant expression of growth factors or growth factor receptors and oncogenes can activate downstream signaling molecules that drive the expression of cyclin D1 [14]. Cell cycle deregulation is crucial for various oncogenic transformation processes, suggesting that many cancer cells depend on high CDK4/6 activity [16-21]. In contrast, the normal development of most tissues can occur in the absence of cyclin D-CDK4/6 complexes [22, 23]. Using strains of genetically modified mice, genetic studies have provided direct evidence for the role of CDK4 in tumor development. Mice lacking cyclin D1 were refractory to mammary tumor development induced by the ErbB2 oncogene, the ortholog of HER2, which is frequently overexpressed in human breast carcinomas [19, 24, 25]. Additionally, mice expressing a mutant form of cyclin D1 that binds to, but does not activate, CDK4 are resistant to erbB2-induced tumorigenesis. The ablation of CDK4 using siRNA in erbB2-induced mammary tumor cells eliminates their oncogenic properties [18]. The loss of CDK4 has also been implicated in the inability of KRasG12-induced lung tumors and c-Myc-induced skin tumors to develop $[16,21,26]$. CDK4/6 activity thus appears to represent a promising therapeutic target for cancer treatment [27-29].

Several highly selective inhibitors of CDK4 and CDK6 are currently being tested in phase II/III clinical trials against a variety of $\mathrm{pRb}$-proficient chemotherapyresistant cancers (http://ClinicalTrials.gov) [30, 31]. The broad-spectrum CKI flavopiridol displayed promising preclinical results in multiple tumor cell types [32-35], but it exhibited adverse effects and high toxicity in early-phase clinical trials [36]; furthermore, it did not meet expectations with regard to efficacy against most tumor types, with the exception of leukemia [34, 37, 38]. Palbociclib (PD0332991) is the first highly selective inhibitor of CDK4/6 to be tested and approved in humans for use in combination with letrozole for the treatment of postmenopausal women with estrogen receptor (ER)-positive human epidermal growth factor receptor 2 (HER2)-negative advanced breast cancer as an initial endocrine-based therapy for metastatic disease. Palbociclib exhibits an in vitro half-maximal inhibitory concentration (IC50) of 10-15 $\mathrm{nM}$ for CDK4/6, compared to $0.5 \mu \mathrm{M}$ for CDK2 [39-41]. In fact, palbociclib has been tested in rabdomyosarcoma [42] and liposarcoma harboring elevated CDK4 expression $[43,44]$. Recently, palbociclib has entered a phase II trial in patients with advanced CDK4-amplified or well differentiated liposarcoma [44]. Preclinical studies have demonstrated that palbociclib induces $\mathrm{G} 1$ arrest in pRbpositive cell lines and suppresses the growth of various xenografted tumors [31, 39-41, 45]. In different cancer models, treatment with PD0332991 not only exerts a cytostatic effect but also induces either the senescence or the apoptotic cell death of tumoral cells [46]. The only known mechanism of resistance to CDK4/6 inhibition is the loss of $\mathrm{pRb}$ function [16, 31, 45, 47]. However, other mechanisms such as p16 $6^{\text {ink4a }}$ loss, cyclin D1 overexpression of elevated CDK2 expression have been proposed [31, 48, 49].

In the present work, we tested the suitability of CDK4 inhibition using palbociclib for sarcomas and explored possible markers of efficacy that are independent of the sarcoma tumor type. We found that tumor cells and patient-derived xenografts (PDXs) respond more strongly to a CDK inhibitor when they express high levels of CDK4 but exhibit resistance to the CDK inhibitor when they express high levels of $\mathrm{p} 16^{\text {ink4a }}$.

\section{RESULTS}

\section{Palbociclib induces senescence in sarcoma cell lines from different origins}

To explore the effect of CDK4 inhibition, we used a panel of 10 low-passaged sarcoma cell lines generated directly from patient samples and 2 commercial cell lines of heterogeneous origin and different molecular karyotypes (Table 1) [53, 54, 57]. We treated these 12 sarcoma cell lines with different concentrations of palbociclib and obtained an IC50 of for each cell line. All responses were in the low $\mu \mathrm{M}$ range (Table 1). These values are higher than the reported in breast tumor cell lines $[40,58,59]$.

To explore in detail the effect of this CDK inhibitor, we selected four different cell lines and 
Table 1: Characteristics of the sarcoma cell lines used and their response to palbociclib

\begin{tabular}{|c|c|c|c|}
\hline Cell lines & Sarcoma type & Karyotype & $\begin{array}{l}\text { Palbociclib } \\
\text { IC50, } \mu \mathrm{M}\end{array}$ \\
\hline AW & Mixoid Liposarcoma & $46, \mathrm{XY} / 47+3 / 50 \% / 50 \%$ & $16.44 \pm 1.62$ \\
\hline AA & Leiomyosarcoma & $\left.\begin{array}{c}55-63<3 \mathrm{n}>\mathrm{XXY},-3,-4,-8, \mathrm{i}(8)(\mathrm{q} 10), \operatorname{add}(8)(\mathrm{p} 23), \operatorname{der}(11) \mathrm{t}(5 ? ; 11) \\
(\mathrm{q} 13 ; \mathrm{p} 15),-12,-13,-14,-16, \operatorname{der}(1 ; 7)(\mathrm{t}(17 ; ?)(\mathrm{p} ? ; ?),-18,-22, \operatorname{mar} 1-3\end{array}\right]$ & $26.63 \pm 2.20$ \\
\hline SW872 & Liposarcoma & $\begin{array}{c}(5) \dagger(5 ; ?)(\mathrm{q} 31 ; ?) 1, \operatorname{dre}(5) \dagger(5 ; ?)(\mathrm{q} 31 ; ?) 2, \operatorname{der}(6) \dagger(6 ; ?)(\mathrm{q} 15: ?), \operatorname{der}(7) \\
+(7 ; ?)(\mathrm{q} 36 ; ?), \mathrm{t}(15 \mathrm{q} 16 \mathrm{q}\end{array}$ & $15.79 \pm 0.13$ \\
\hline $\mathrm{BD}$ & Ewing's sarcoma & $46, X Y$ & $23.07 \pm 2.33$ \\
\hline $\mathrm{AX}$ & Mixoid Liposarcoma & $\begin{array}{c}62-65,<3 \mathrm{n}>,-3,-4,-5,+7, \operatorname{der}(7) \dagger(7 ; ?), \operatorname{add}(8)(\mathrm{p} ?), \mathrm{i}(8) \\
(\mathrm{q} 10),-9,-11, \operatorname{der}(11) \dagger(5 ; 11),-13, \operatorname{add}(14)(\mathrm{q} 32),-15, \mathrm{x} 2,-16,-18,+1- \\
4 \mathrm{mar} \mathrm{cp} 5]\end{array}$ & $16.90 \pm 0.20$ \\
\hline BG & Myxofibrosarcoma & 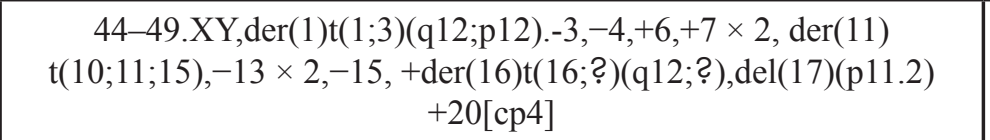 & $20.96 \pm 0.04$ \\
\hline $\mathrm{BC}$ & MPNST & $46, X X$ & $12.43 \pm 1.01$ \\
\hline $\mathrm{AZ}$ & Fibrous tumor & $46, \mathrm{XX} / 47, \mathrm{XX}+8 / 50 \% / 50 \%$ & $17.42 \pm 5.46$ \\
\hline A673 & Ewing's sarcoma & 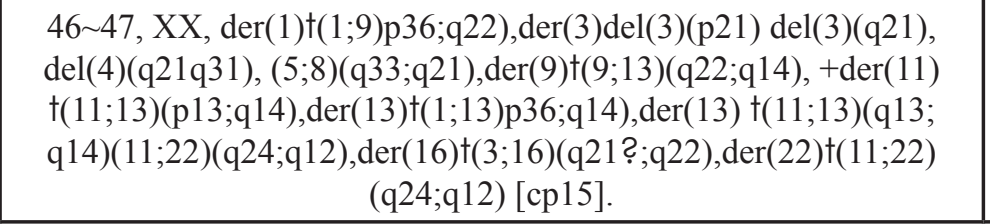 & $8.95 \pm 0.40$ \\
\hline $\mathrm{CE}$ & Rhabdomyosarcoma & $46, X Y$ & $15.72 \pm 1.17$ \\
\hline DA & MPNST & ND & $25.9 \pm 1.34$ \\
\hline DD & Myxofibrosarcoma & ND & $16.65 \pm 0.15$ \\
\hline
\end{tabular}

The IC50 was calculated from the average of a minimum of 3 independent experiments performed on triplicate samples

measured the effect produced by palbociclib. We found that in all cell lines tested, palbociclib induced growth arrest at $\mathrm{Go} / \mathrm{G} 1$ based on the detection of markers of cellular senescence (Figure 1). After 4 days of treatment, palbociclib induced the formation of nuclear foci containing the 53BP1 protein (Figure 1A), concomitant with strong SA B-Gal staining (Figure 1B) and reduced $\mathrm{pRb}$ phosphorylation (Figure 1C), as expected from the CDK4/6 inhibitory activity of palbociclib. However, we did not detect a significant change in the $\mathrm{p} 16^{\text {ink4a }}$ levels. Moreover, in the BG cell line, the only cell line harboring wild type p53, treatment with palbociclib did not significantly alter p2 $1^{\text {wafl }}$ protein expression (Figure 1C).

\section{Role of the CDK4 levels in the response of sarcoma cell lines to palbociclib}

Although we examined a limited number of cell lines, which may limit the relevance of the findings, we next set up to explore whether the activity of palbociclib correlates with any molecular characteristics of the cells. Initially, we did not find any correlation of the palbociclib response with tumor type or the complexity of the karyotype (Figure 2A). It has been reported that in different cell models, the activity of palbociclib may be related to the $\mathrm{p} 16^{\text {ink4a }}$, cyclin D1 or CDK4 levels. The levels of these factors were characterized in our cell lines (table 2, Supplementary figure S1), and we analyzed their correlation with the efficacy of palbociclib. We found that in vitro, the sensitivity of palbociclib is related to high CDK4 levels, either at the mRNA (Student's T test, $p=0.017$ ) or the protein level (Student's T test, $p=0.077$ ) (Figure 2A), but not to the levels of p16 $6^{\text {inkaa }}$, cyclin D1 or p53 (Figure 2A).

To further explore the functional relevance of CDK4 levels to the efficacy of CDK inhibitors, we treated a panel of cell lines with flavopiridol and performed similar analyses (Supplementary Table S1). We found a similar correlation between the sensitivity of the cells to the CDK inhibitor and their levels of CDK4 (Supplementary Figure S3). As in palbociclib, we did not find any correlation between sensitivity to flavopiridol in vitro and the levels of $\mathrm{p} 16^{\text {ink4a }}$ or cyclin D1 or the sarcoma type (Data not shown). 

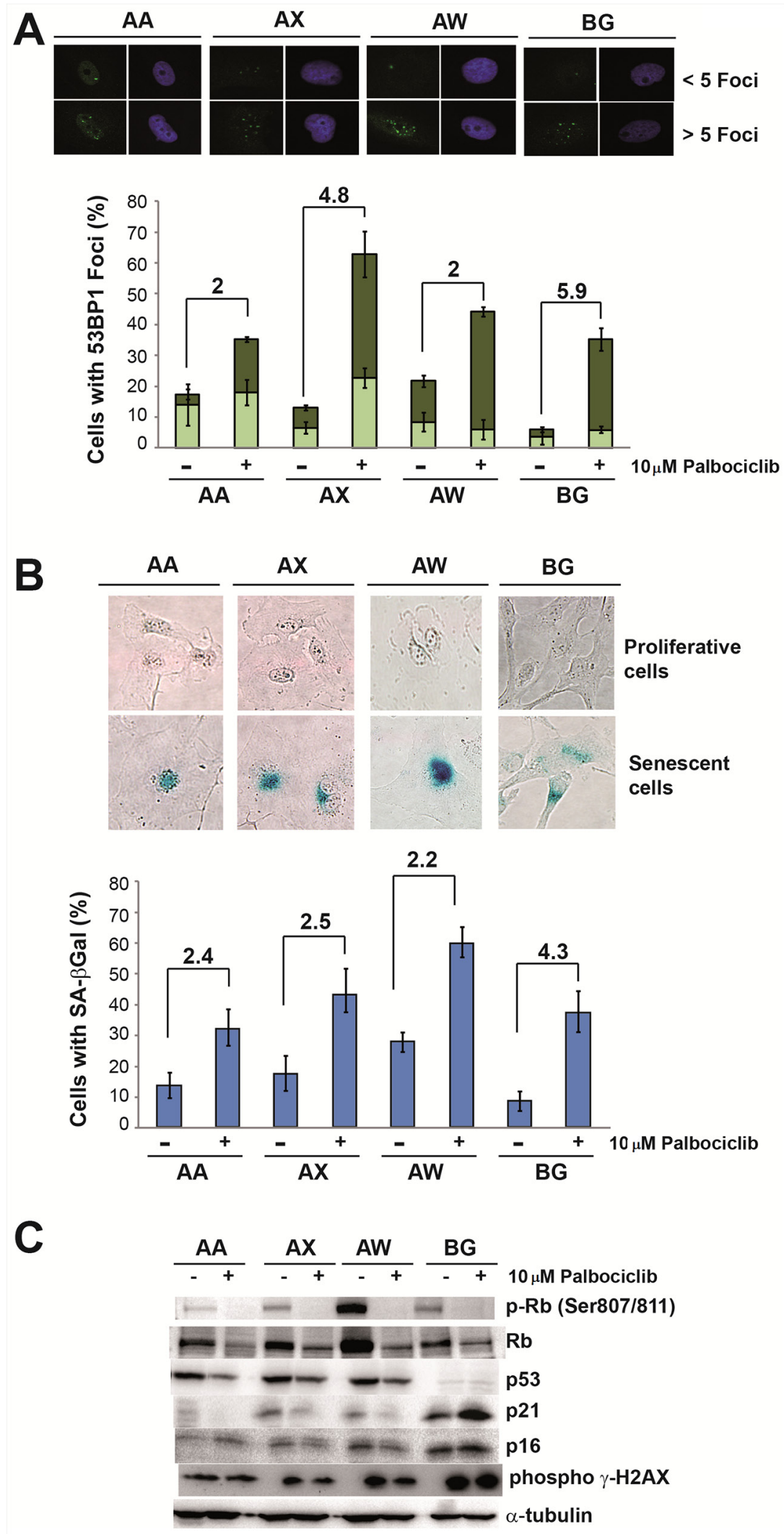

Figure 1: Palbociclib induces senescence markers in sarcoma cell lines. A. Analysis of the levels of 53BP1 foci. Representative images (top) and quantification (bottom) of 53BP1 foci in the AA, AW, AX and BG sarcoma cell lines in the presence or absence of 10 $\mu \mathrm{M}$ palbociclib. B. Analysis of senescence-associated $\beta$-galactosidase (SA $\beta$-Gal) activity. Representative images (top) and quantification (bottom) of SA $\beta$-Gal activity in the AA, AW, AX and BG sarcoma cell lines in the presence or absence of $10 \mu \mathrm{M}$ palbociclib. C. Western blot analysis of senescence markers in the AA, AW, AX and BG sarcoma cell lines in the presence or absence of $10 \mu \mathrm{M}$ palbociclib. 

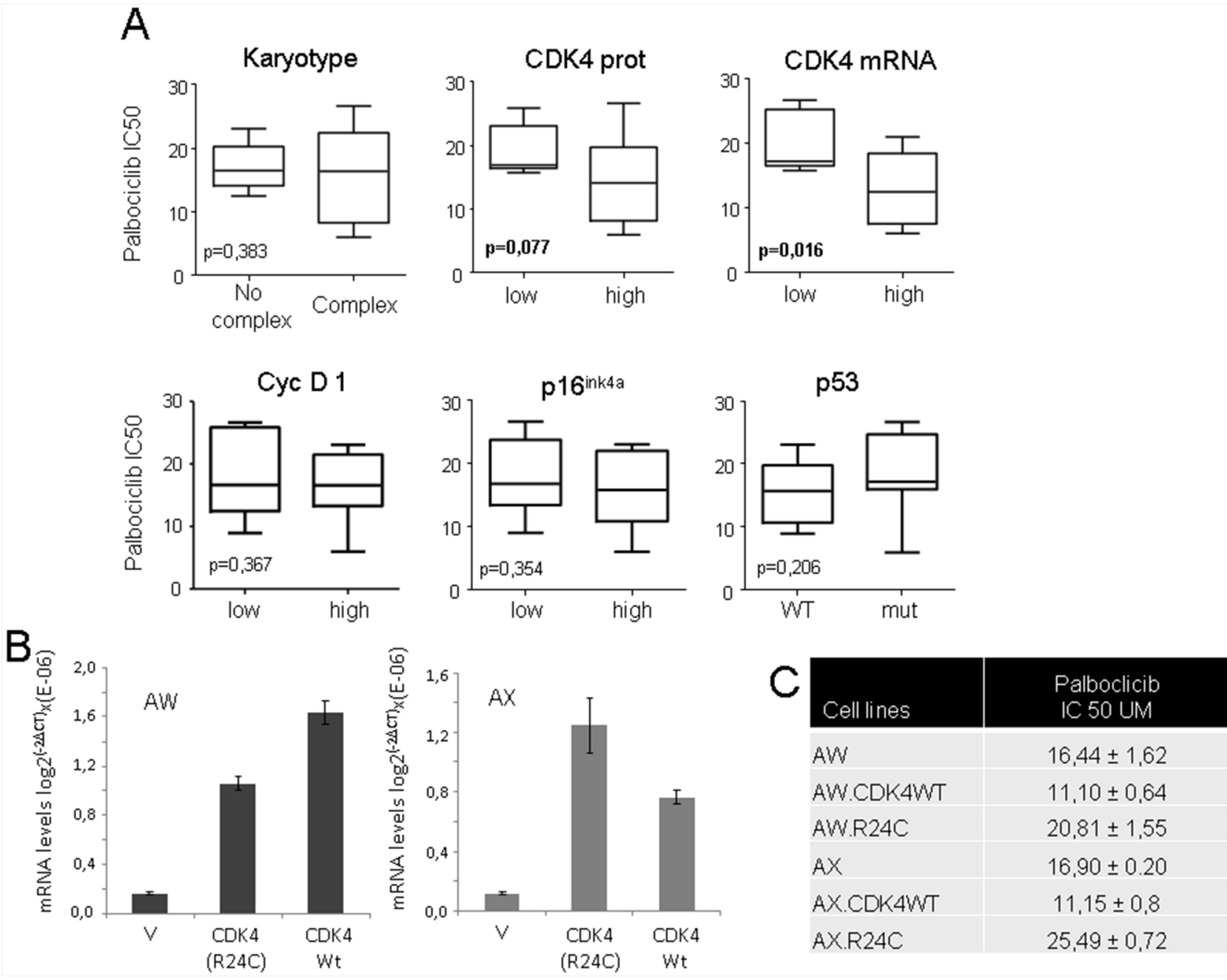

Figure 2: Correlation of the CDK4 expression level in sarcoma cell lines with their sensitivity to palbociclib. A. Correlation of the levels of different cell cycle proteins with the cellular sensitivity to palbociclib. We analyzed the correlation (Student's $t$ Test) of the presence or absence of mutant $\mathrm{p} 53$, p16 ${ }^{\text {ink4a }}$, or cyclin D1, the CDK4 levels (as shown in table 2) or a complex karyotype (as shown in table 1) with the response to palbociclib. Increased sensitivity of palbociclib was related to high CDK4 levels at the mRNA (Student's $T$ test, $p=0.017$ ) or protein level (Student's $T$ test, $p=0.077$ ), but not to the cellular karyotype or $\mathrm{p} 16 \mathrm{ink} 4 \mathrm{a}$, cyclin D1 or $\mathrm{p} 53$ status. B. AW and AX cells were transfected with empty vector (V) or a plasmid containing cDNA for wild type CDK4 (CDK4) or mutant CDK4-R24C (R24C). The graphs show the levels of mRNAs in the generated mass cultures after selection. C. IC50 of palbociclib for the $\mathrm{AX}$ and AW sarcoma cell lines and the generated lines overexpressing wild type CDK4 or mutant CDK4-R24C (R24C). The IC50 was calculated as the average of a minimum of 3 independent measurements performed on triplicate samples.

To study the functional relationship between the CDK4 levels and the cellular response to palbociclib, we overexpressed wild type CDK4 cDNA in 2 different sarcoma cell lines, AW and AX (Figure 2B). Because it has been reported that $\mathrm{CDK} 4^{\mathrm{R} 24 \mathrm{C}}$, an active mutant of CDK4, is present in human tumors (athough not reported in sarcomas) and cannot be inhibited by members of the INK4 family, we decided to overexpress this mutant in these sarcoma cells (Figure 2B) in order to gain insight on palbociclib mechanism by exploring the effect of $\mathrm{CDK}^{\mathrm{R} 24 \mathrm{C}}$ on its cellular response. An increased sensitivity to palbociclib was observed in cells overexpressing wild type CDK4, whereas the overexpression of the CDK4 ${ }^{\mathrm{R} 24 \mathrm{C}}$ mutant increased the resistance of both sarcoma cell lines to palbociclib (Figure 2C).

Next, we analyzed the effect of palbociclib on these engineered cell lines. We found that palbociclib induced cellular senescence in parental cells and in cells overexpressing wild type CDK4 (Figure $3 \mathrm{~A}$ and 3B). The levels of senescence markers positively correlated with a reduction in the levels of phosphorylated $\mathrm{pRb}$ and an increase in the $16^{\text {ink4a }}$ and $\mathrm{p} 21^{\text {cip } 1}$ levels (Figure 3C). Alternatively, the induction of senescence markers was not observed in cells overexpressing the CDK4 ${ }^{\mathrm{R} 24 \mathrm{C}}$ mutant; these cells preferentially entered apoptosis after palbociclib 
Table 2: Presence or absence of certain cell cycle-related proteins in the cell line panel used in this study

\begin{tabular}{|c|c|c|c|c|c|}
\hline Cell line & P53 mut & P16 INK4 (1) & Cус D1(2) & CDK4 prot (3) & CDK4 mRNA (4) \\
\hline $\mathrm{AA}$ & $273 \mathrm{H}$ & 0 & 0 & 1 & 0 \\
\hline AW & $273 \mathrm{H}$ & 0 & 0 & 0 & 0 \\
\hline $\mathrm{AX}$ & $273 \mathrm{H}$ & 0 & 0 & 0 & 0 \\
\hline $\mathrm{AZ}$ & WT & 0 & 1 & 1 & 0 \\
\hline $\mathrm{BD}$ & WT & 1 & 1 & 0 & 0 \\
\hline $\mathrm{BC}$ & WT & 0 & 1 & 1 & 1 \\
\hline BG & Del & 1 & 1 & 0 & 1 \\
\hline DA & $273 \mathrm{H}$ & 0 & 0 & 0 & 0 \\
\hline DD & $175 \mathrm{H}$ & 0 & 0 & 0 & 0 \\
\hline $\mathrm{CE}$ & WT & 1 & 0 & 0 & 0 \\
\hline A673 & WT & 0 & 1 & 1 & 1 \\
\hline SW872 & $251 \mathrm{~N}$ & 1 & 0 & 0 & 1 \\
\hline
\end{tabular}

(1): 1: presence of mRNA; 0 : absence of mRNA

(2): 1: overexpression of protein; 0 : absence or low levels of protein

(3): 1 : high levels of protein; 0 : normal levels of protein

(4): 1: high levels of mRNA; 0 : normal levels of mRNA

treatment (Figure 3D and Supplementary figure S3), although some apoptosis was also detected in the parental cells and in the cells overexpressing wild type CDK4 (Figure 3D and Supplementary figure S3).

\section{Effect of CDK4 inhibition on sarcoma PDXs}

To explore the effect of CDK4 inhibition in vivo, we used PDX models produced from a panel of different types of sarcoma. We selected 6 tumors from different tissue origins (Figure 4A). The comparison of the entire transcriptome of these tumor xenografts to the original human tumor showed between 93 and $98 \%$ similarity (Figure 4B), indicating that the PDX models were almost identical to the original human sarcomas. From these sarcomas, we tested 2 samples expressing high levels of CDK4 and cyclin D1 (S11 and S16), 2 samples expressing high p16 $6^{\text {inkta }}$ levels (S23 and S27), and two samples expressing normal levels of CDK4, low levels of cyclin D1 and no detectable p16 ${ }^{\text {ink4a }}$ (S14 and S29) (Figure 4C). The sarcomas were subcutaneously engrafted and grown until all tumors reached $50 \mathrm{~mm} 3$ in volume. Then, the animals were treated with palbociclib. On the day after the final dose, mice harboring each tumor subtype treated with solvent (untreated) or with palbociclib (treated) were sacrificed, and the tumors analyzed for the expression of KI67, a marker of proliferation (Figure 5A). We found a variable effect of to palbociclib administration on the different sarcomas. Whereas some PDXs such as S11, S14 and S23 displayed a clear decrease in proliferation, others such as S29, did not show any effect of to palbociclib administration on KI67 expression (Figure 5A).

To explore the effect of palbociclib in these tumors we analyzed the response of cell cycle related proteins to palbociclib (Figure 5B). Thus, we collected the tumors the day after treatment from the same tumors and analyzed by western blot the the cell cycle relates proteins in tumors untreated and treated with palbociclib (Figure 5B). We can appreciate that palbociclib induces a decrease in all cell cycle related proteins, with a clear effect on $\mathrm{pRb}$ phosporylation in all models, either responding or not responding, as well as CDK4, confirming the activity of palbociclib in all models.

However, we observed different tumor behavior in response to the CDK4 inhibitor. Although we observed an initial inhibition of tumor growth in all tumors (Figure 6), after ending the treatment, the different sarcomas behaved very differently. The tumors expressing high CDK4 levels (S11 and S16) responded to the drug (figure 6). S16-derived tumors stop growing and even reduced in size in response to the treatment; as result, all treated mice survived. Alternatively, the S11-derived tumors responded to CDK4 inhibition by greatly delaying tumor growth; as a result, the treated mice survived almost twofold longer than the untreated mice (Figure 6). However, the two tumors expressing high $\mathrm{p} 16^{\text {ink4a }}$ and normal CDK4 levels, (S23 and S27), showed some initial response to the CDK4 inhibitor, but after ending the treatment, tumor growth recovered to an even faster rate than that of the untreated tumors, and the survival of the treated mice was 

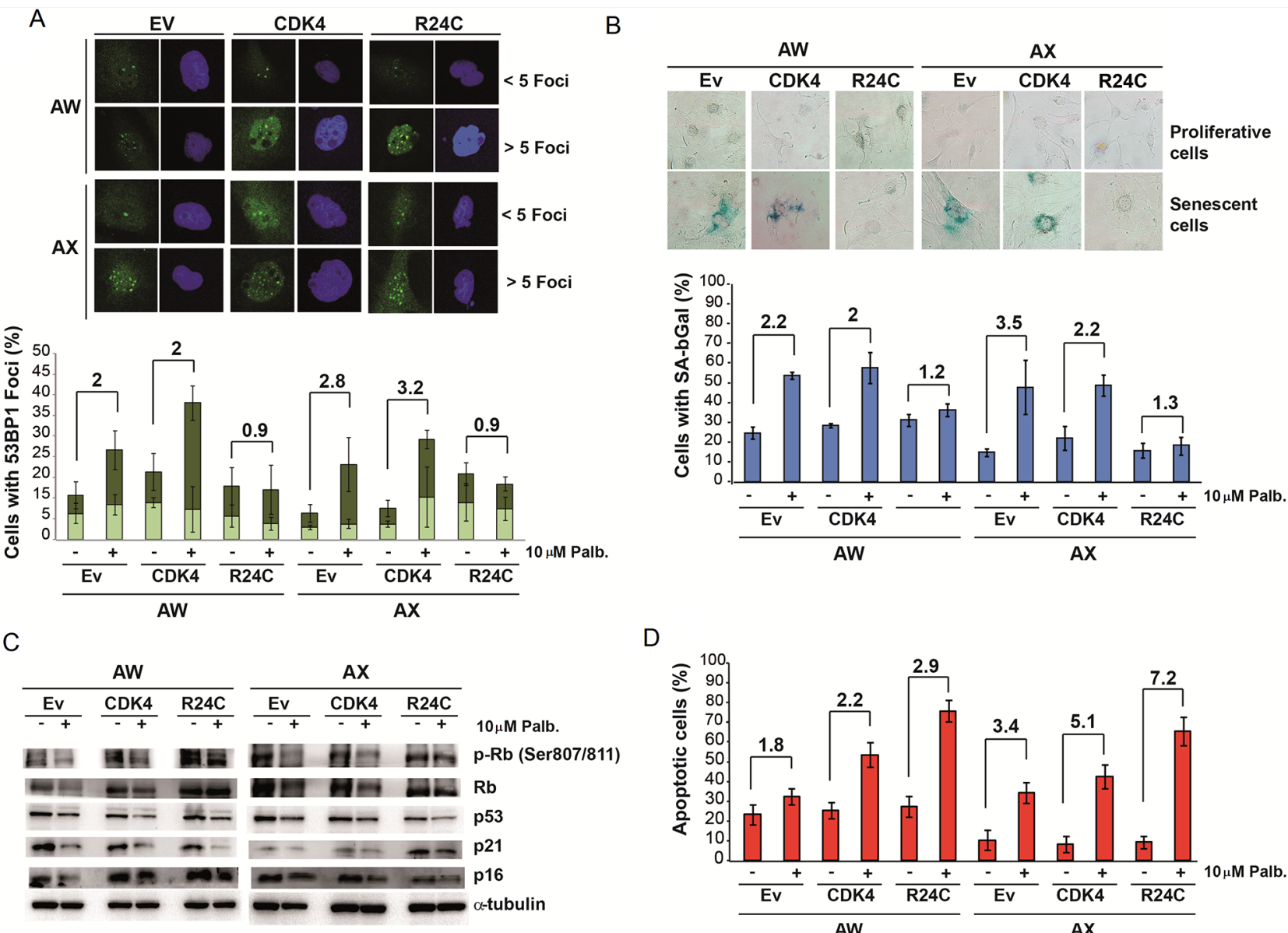

D

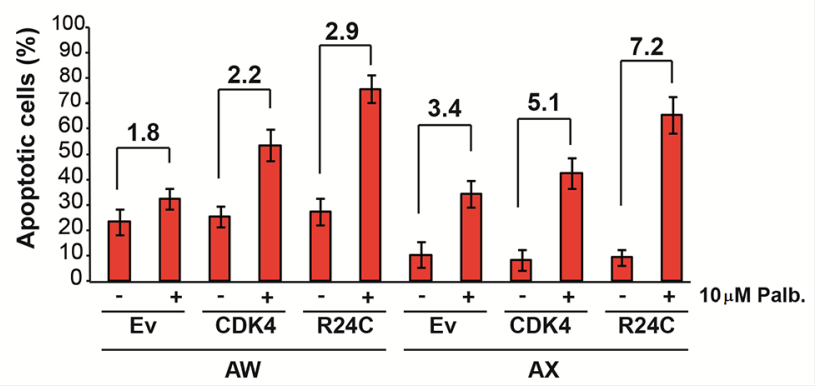

Figure 3: Physiological effect of palbociclib on cells overexpressing wild type CDK4 or INK4-insensitive mutant CDK4-R24C. A. Analysis of the levels of 53BP1 foci. Representative images (top) and quantification (bottom) of 53BP1 foci in the $\mathrm{AX}$ and AW sarcoma cell lines transfected with empty vector (Ev) or a plasmid overexpressing CDK4 (CDK4) or mutant CDK4-R24C (R24C) after treatment with $10 \mu \mathrm{M}$ palbociclib. B. Analysis of senescence-associated $\beta$-galactosidase (SA $\beta$-Gal) activity. Representative images (top) and quantification (bottom) of SA $\beta$-Gal activity in AX and AW sarcoma cells lines transfected with empty vector (Ev) or a plasmid overexpressing CDK4 (CDK4) or mutant CDK4-R24C (R24C) after treatment with $10 \mu \mathrm{M}$ palbociclib. C. Western blot analysis of senescence markers in AX and AW sarcoma cells transfected with empty vector (Ev) or a plasmid overexpressing CDK4 (CDK4) or mutant CDK4-R24C (R24C) after treatment with $10 \mu \mathrm{M}$ palbociclib. D. Percentage of apoptotic cells among AX and AW sarcoma cells transfected with empty vector (Ev) or a plasmid overexpressing CDK4 (CDK4) or mutant CDK4-R24C (R24C) after treatment with $10 \mu \mathrm{M}$ palbociclib.

very similar to that of the untreated controls (Figure 6). Finally, the two tumors expressing normal CDK4 levels but low p16 $6^{\text {inkat }}$ levels showed heterogeneous responses. The MPNST-derived S14 PDXs responded to CDK4 inhibition with a clear reduction in tumor growth rate, and we even observed one tumor that disappeared in a mouse that survived. Alternatively, the S29-leiomiosarcoma responded initially to the CDK4 inhibitor, but after ending the treatment, tumor growth recovered, and the survival of the treated mice was only slightly longer than that of the untreated controls (Figure 6). We do not know whether a second round of treatment with palbociclib would have been more efficacious in these sarcomas because all of them appeared to respond to the first round of treatment; however, in some samples (S29), we did not observe a clear decrease in the expression of the proliferation marker KI67 (Figure 5). These data agree with the in vitro cellular data, suggesting that tumors expressing high CDK4 levels respond more strongly to palbociclib.

At the end of the experiment, we collected all growing tumors and analyzed the levels of different proteins that may be involved in the response and/or the re-growth of the sarcoma. This could help us to determine whether molecular drift occurred in these tumors in response to the treatment and to identify possible drug resistance mechanisms. The tumors, either treated or untreated, from the same initial engraft were individually processed, and the levels of certain cell cycle proteins were analyzed (Figure 7 shows 3 representative untreated and treated tumors from the 5 models in which we detected re-growth of the treated sarcomas).

We observed that, in general, untreated tumors maintained or even increased their levels of CDK4, whereas most treated counterparts showed greatly reduced 
A

\begin{tabular}{|l|c|}
\hline \multicolumn{1}{|c|}{ Tumor } & Hystology \\
\hline S11 & High grade Myxofibrosarcoma \\
\hline S14 & MPNST \\
\hline S16 & Myxofibrosarcoma \\
\hline S23 & Non-differentiated pleomorfic sarcoma \\
\hline S27 & High grade pleomorfic sarcoma \\
\hline S29 & Leiomiosarcoma \\
\hline
\end{tabular}

B

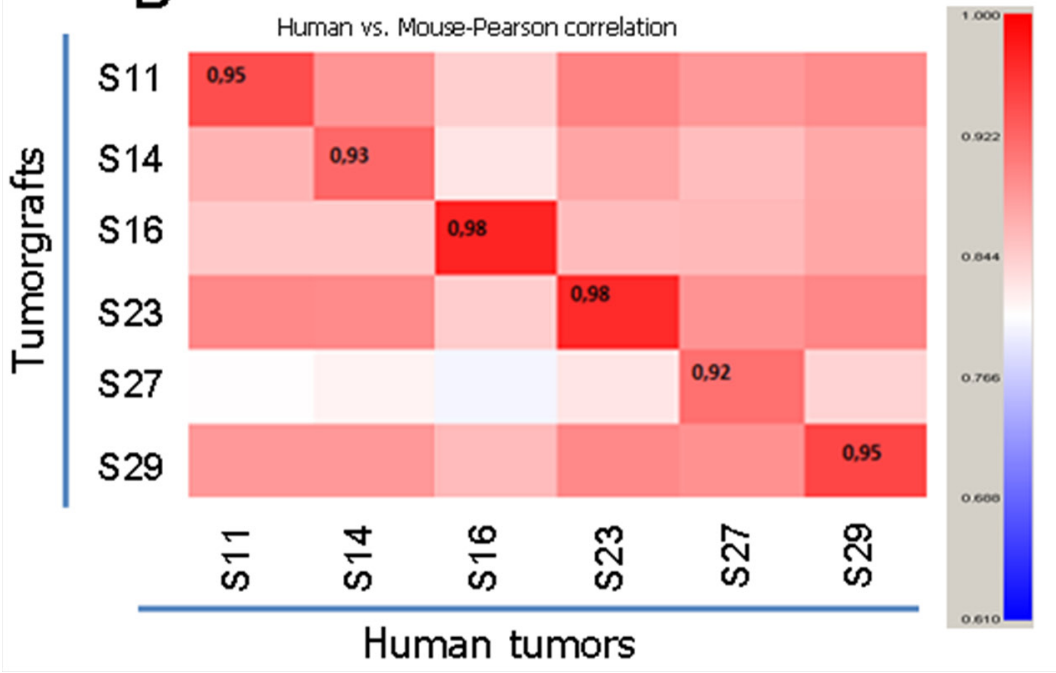

Q
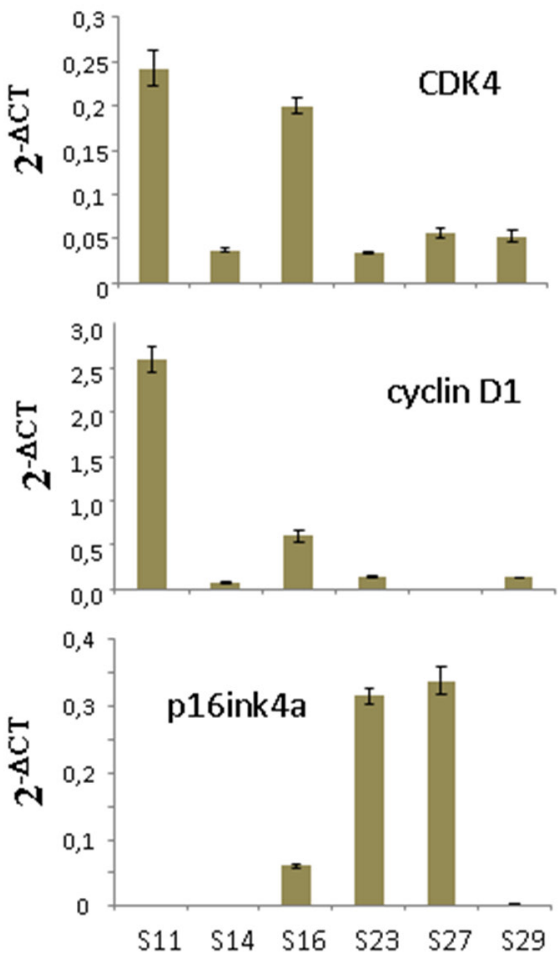

Figure 4: Characteristics of the PDXs used in this study. A. Tumor histology of the 6 sarcoma PDX samples used. B. Comparison of the complete transcriptional profile of the original human tumor with the tumor graft grown in immunosuppressed mice. The number in the inset shows the correlation ( 0 to 1 ) between the original human tumor and the PDX used to explore the efficacy of palbociclib. C. The levels of CDK4, p16ink4 and cyclin D1 mRNA in the xenografted tumors used in this study.

levels of this protein (Figure 7). We also observed some heterogeneity among the treated tumors, including some tumors that expressed high CDK4 levels, indicating the independent evolution of individual clones. We did not detect any association of palbociclib treatment with the behavior of phospho-pRb, measured at three independent sites, as high heterogeneity in the $\mathrm{pRb}$ levels was observed among clones. In our case, an increase in the $\mathrm{pRb}$ level appears not to be a determinant of treated tumor regrowth. Similar results were obtained in the site of CDK4 phosphorylation of $\mathrm{p} 30$, other pocket protein of $\mathrm{pRb}$ family. Similarly, we did not detect any association of the p $16^{\text {ink4a }}$, cyclin D1 or CDK2 levels with the re-growth of treated tumors (Figure 7). Surprisingly, only an increase in $\mathrm{p} 21^{\mathrm{cip} 1}$ expression was observed in the tumors in treated animals xenografted with responsive sarcomas (S14 and S11).

\section{DISCUSSION}

The recent development of selective CDK4 inhibitors launched the first successful efforts to target the CDK4 pathway for cancer therapy. Several selective CDK4/6 inhibitors are currently in development, and these agents appear to be better tolerated than previous generations of CDK4 inhibitors. Three oral selective CDK4 inhibitors have entered clinical trials: palbociclib (PD0332991), LEE011, and LY2835219. CDK4 inhibitors display in vitro activity against a broad range of cancers and antitumor activity in patients with breast cancer, lymphoma, sarcoma, and other tumors [31, 60, 61]. Major efforts are underway to develop biomarkers of the treatment response and to understand the potential mechanisms underlying resistance to CDK4 inhibitors $[31,61]$.

To study the effect of CDK4 inhibition in sarcoma, a tumor type with few therapeutic approaches, we examined the effects of the CDK4 inhibitor palbociclib on sarcoma cell lines and PDX models. Treating these sarcoma tumors with the CDK4 inhibitor palbociclib revealed that tumors expressing high levels of CDK4 mRNA, but not those expressing low CDK4 and high p16 $6^{\mathrm{INK} 4 \mathrm{a}}$ levels, responded to palbociclib. On the other hand, we have 

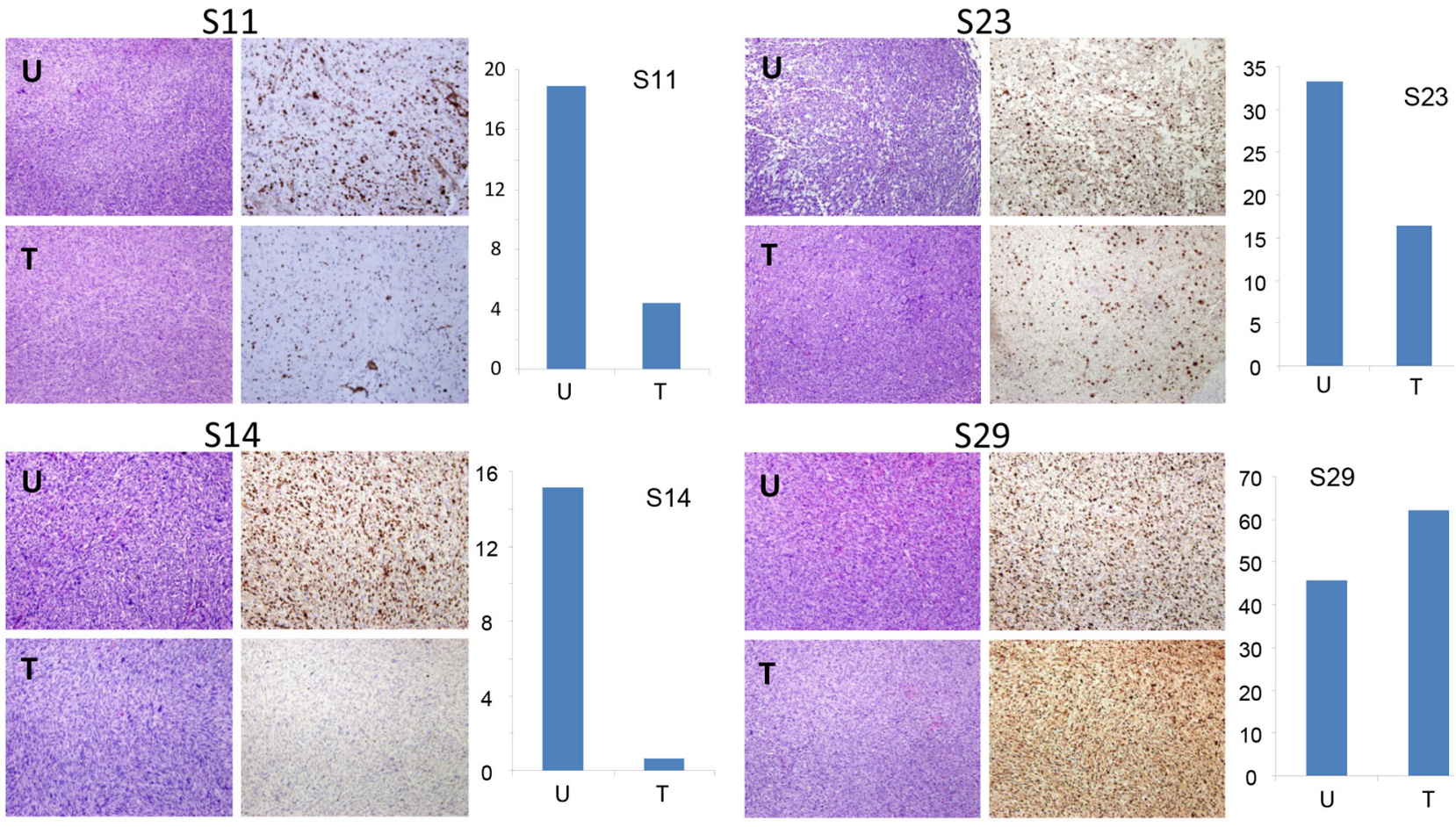

$\$ 29$
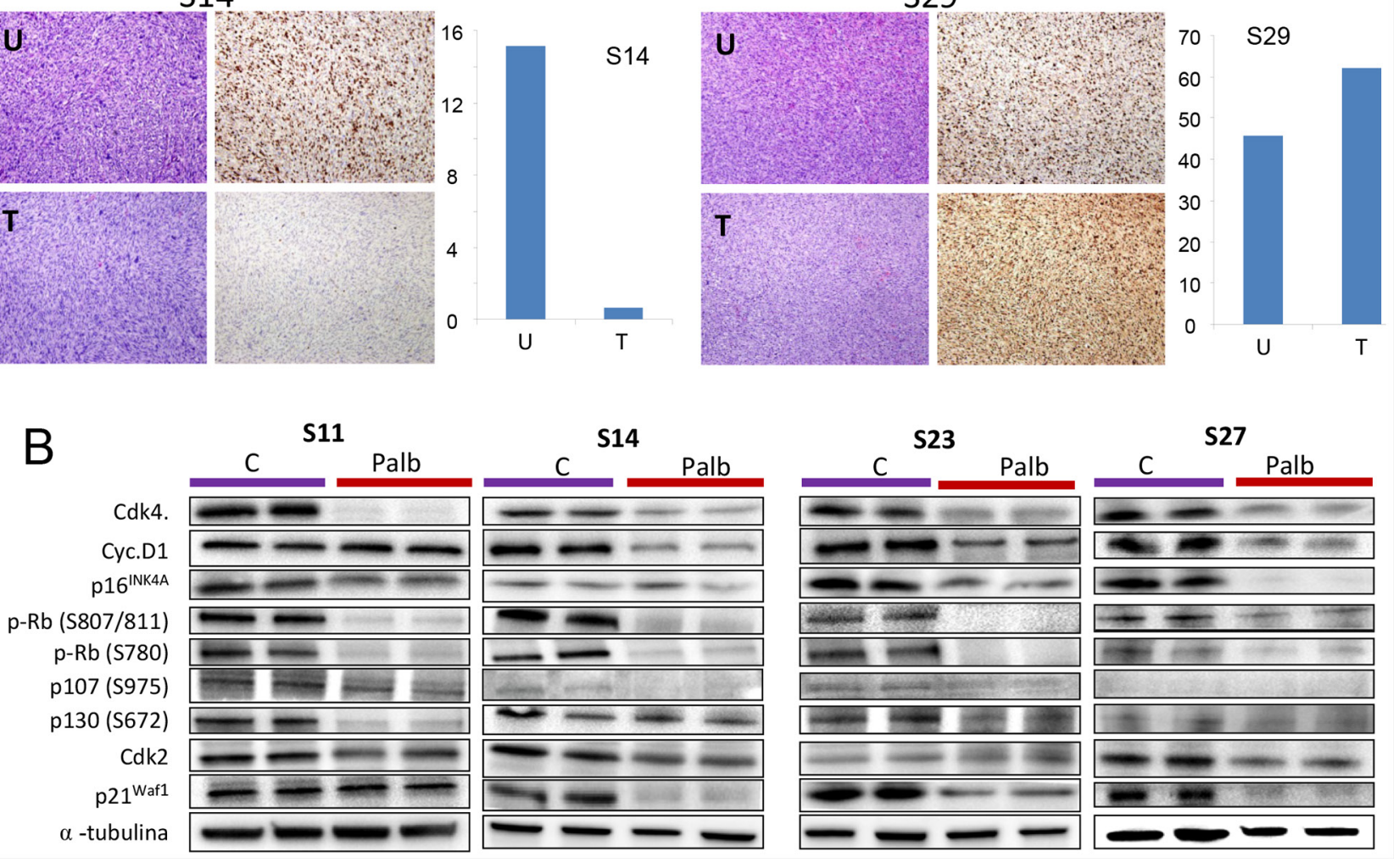

Figure 5: Effect of palbociclib on proliferation in vivo. The sarcomas were subcutaneously engrafted and grown until all tumors reached $50 \mathrm{~mm} 3$ in volume. Then, the mice were treated with $2 \mathrm{mg} /$ dose palbociclib for 3 weeks ( 5 days per week) via oral administration. The tumors were measured twice a week. The day after the final dose, the tumor-bearing mice treated with solvent (untreated) or palbociclib (treated) were sacrificed, and the tumors were analyzed for the expression of A. KI67, a marker of proliferation, B. several cell cycle related proteins by western blot. The tumors from the same initial engraft in both the treated or untreated groups were individually processed, and the levels of certain cell cycle proteins were analyzed. Western blots for CDK4, cyclin D1, phosphor-pRb (at Ser807/811; at S780), CDK2, p21waf1, p16ink4a, phospho-p130 (at S762), phospho-p107 (at S975) and a-tubulin (loading control) are shown. The figure shows 2 representative untreated and treated tumors from 4 models of the treated sarcomas.

found that CDK4-R24C mutant increases resistance to the drug. Since the only known phenotype associated to the R24C mutation is the insensitivity to Ink4 inhibitors the mechanistic basis of this result is unclear. Palbociclib selectively binds the ATP binding site of the CDK4/6cyclin D complex. It is possible that mutation in $\mathrm{R} 24 \mathrm{C}$ of CDK4 slightly disturbs the ATP-binding pocket providing lower affinity of palbociclib for mutant CDK4, thus rendering this protein more resistant to its inhibition. We think that further crystallography studies with the mutant vs WT CDK 4 proteins bound to the drug are necessary.

It has been reported that the efficacy of CDK4 inhibitors requires that the tumor cell express a normally functioning $\mathrm{pRb}$. If there is loss of the intact $\mathrm{pRb}$, then the G1 checkpoint becomes unrestricted, rendering the proliferation of malignant cells CDK4/6-independent 

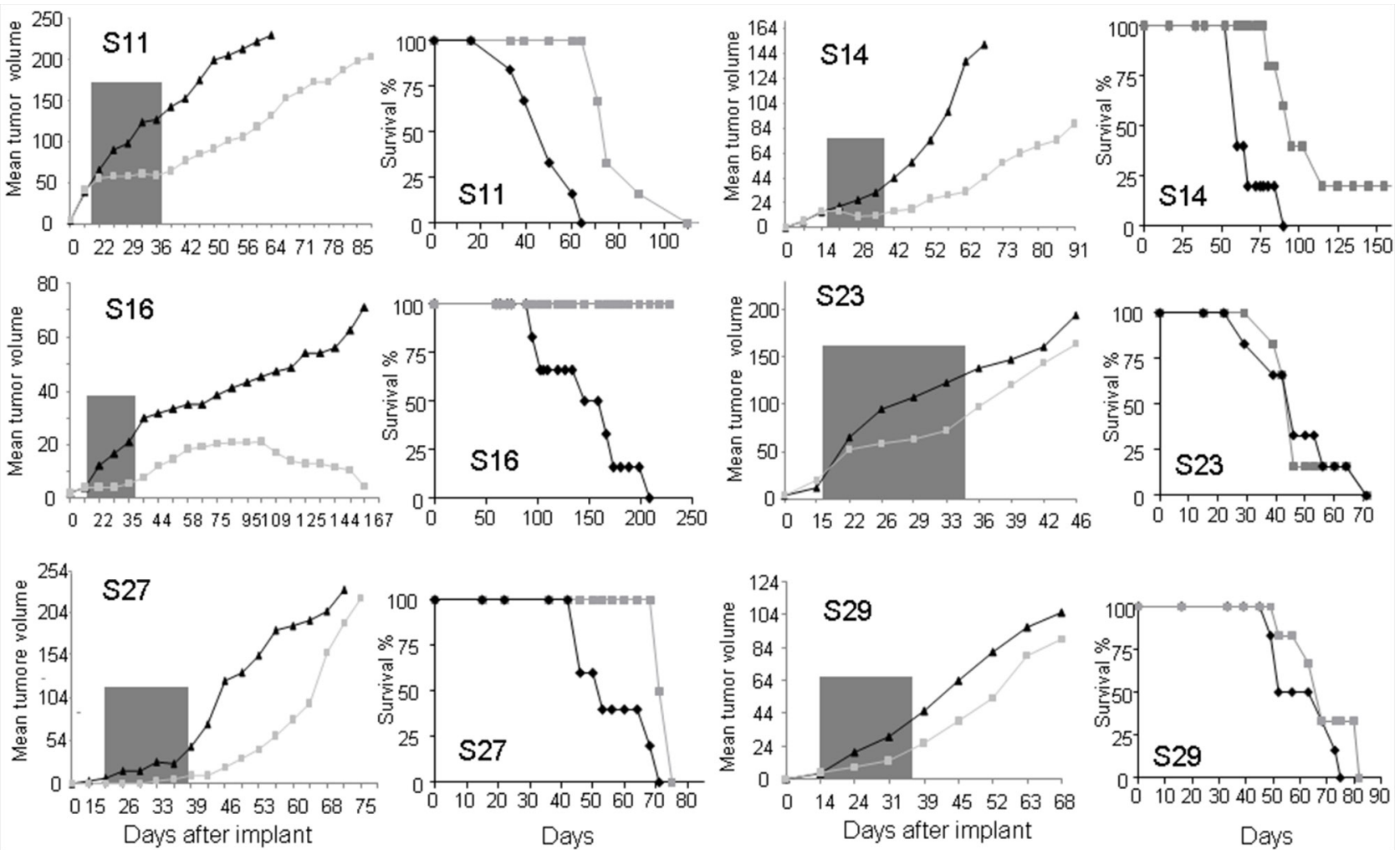

Figure 6: Effects of palbociclib on the sarcoma PDX models used in this study. The sarcomas were subcutaneously engrafted and grown until all tumors reached $50 \mathrm{~mm} 3$ in volume. Then, the mice were treated with $2 \mathrm{mg} /$ dose palbociclib for 3 weeks $(5$ days per week) via oral administration. The tumors were measured twice a week. Graphs showing the average size of all tumors (left) and the survival curve of all mice (right) are presented for each PDX model tested.

and thus resistant to treatment with CDK4/6 inhibitors. However, some cell lines expressing an intact $\mathrm{pRb}$ exhibit CDK4/6 inhibition insensitivity, suggesting that other escape mechanisms exist [31]. Increased levels of $\mathrm{p} 16^{\mathrm{INK} 4 \mathrm{a}}$ may serve as a marker of $\mathrm{pRb}$ deficiency $[62,63]$. In our hands, in vivo studies suggest that high levels of $\mathrm{p} 16$ ink $4 \mathrm{a}$ are a marker of poor response to palbociclib, even in the presence of active $\mathrm{pRb}$ in the tumors as demonstrated by its phosphorylation as diverse sites (Figure 7).

In our in vivo study, a molecular pattern was related to the response to a CDK4 inhibitor. Whereas two sarcomas expressing high CDK4 levels responded (S11 and S16), the two sarcomas expressing high $\mathrm{p} 16^{\mathrm{INK} 4 \mathrm{a}}$ and normal CDK4 levels showed a poor response and early recovery from treatment. However, among the tumors with normal CDK4 levels but low p16 $6^{\mathrm{INK} 4 \mathrm{a}}$, there was some heterogeneity, as one tumor appeared to respond (MPNST-S14) but the other (Leiomiosarcoma-S29) showed similar levels of senescence markers to those in S14; however, the treatment response and the KI67 expression results were unclear. It is possible that leiomyosarcomas in general or this specific tumor are refractory to the drug in vivo. It is also possible that under possible limiting molecular conditions (normal CDK4 medium/low cyclin D and low $\mathrm{p} 16^{\mathrm{INK} 4 \mathrm{a}}$ ), the response is worse than under conditions of the complete absence of $\mathrm{p} 16^{\mathrm{INK} 4 \mathrm{a}}$. However, although we did not observe a correlation with tissue origin in the cell line results (data not shown), the observations that both responsive tumors originated from myxofibrosarcomas and that both clear nonresponders originated from pleomorphic sarcomas suggest that some tumor type-related effect on the treatment response is possible. Thus, additional experiments examining a large cohort of these tumor types are necessary. In line with the results of the responsive MPNST-S14 sample, it is worth mentioning that MPNSTs are sensitive to sorafenib, probably due to the inhibition of MEK and ERK, the suppression of cyclin D1, and the hypophosphorylation of $\mathrm{pRb}$ at CDK4-specific sites, resulting in cell cycle arrest [64]. The available evidence suggests that sorafenib, by inhibiting the MAPK pathway, inhibits CDK4 and that this drug may serve as a novel treatment for patients with MPNST.

As previously mentioned, increased levels of $\mathrm{p} 16^{\mathrm{INK} 4 \mathrm{a}}$ may serve as a marker of $\mathrm{pRb}$ deficiency $[62,63]$. However, high levels of $\mathrm{p} 16^{\mathrm{INK} 4 \mathrm{a}}$ exist also in some tumors with wild type $\mathrm{pRb}$ as in those carrying HPV (E7 protein targets $\mathrm{pRb}$ ), or that over express MDM2 [65], commonly co-amplified with CDK4 in sarcomas. However, in cells, we did not observe a significant correlation of the treatment response with high $\mathrm{p} 16^{\mathrm{INK} 4 \mathrm{a}}$ levels (Figure 3 ), and we detected $\mathrm{pRb}$ in all tumors (Figures 5 and 7). 

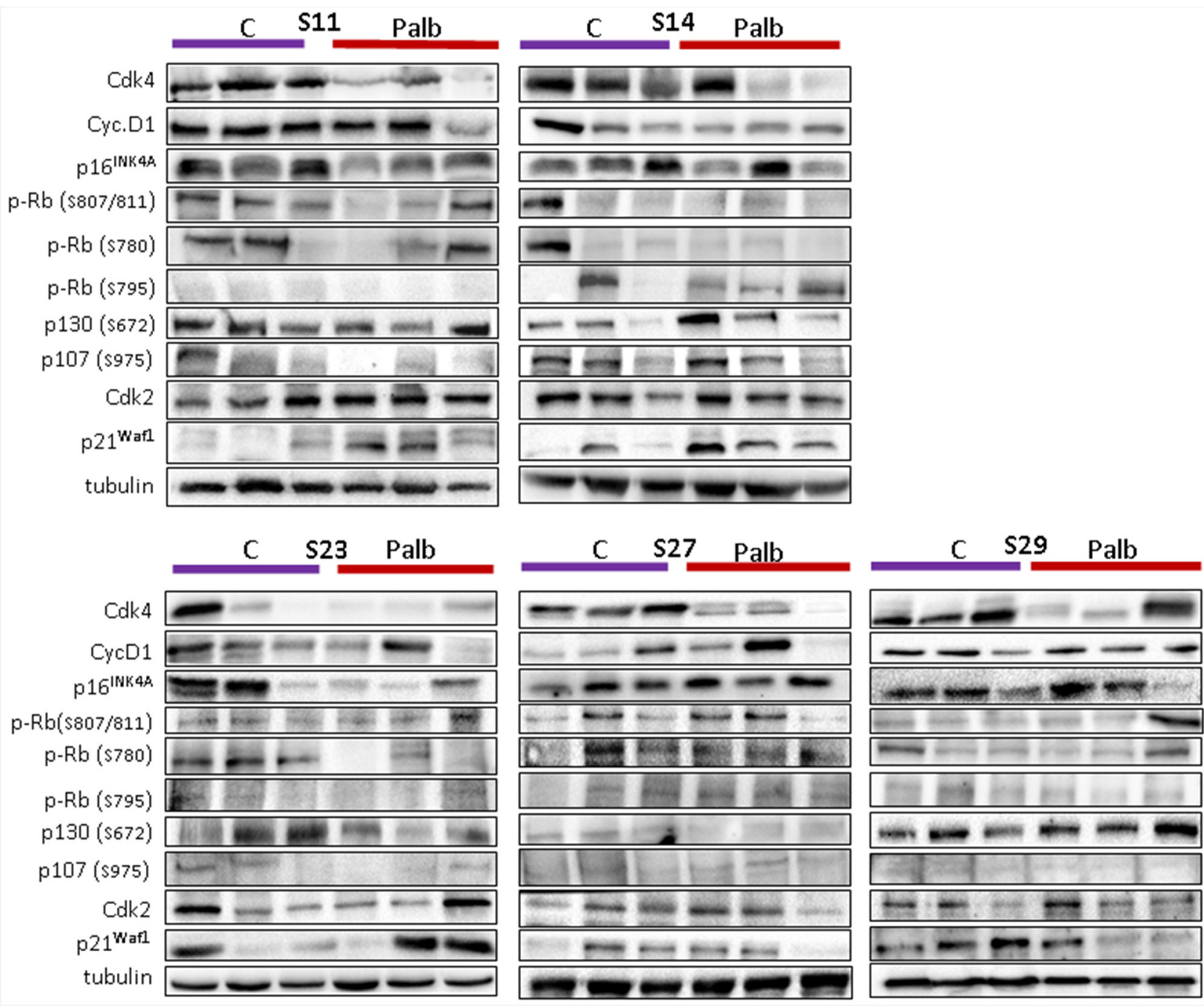

Figure 7: Levels of different cell cycle-related proteins in the sarcomas grown in untreated or treated mice. At the end of the experiment, we collected all growing tumors and analyzed the levels of different proteins that may be involved in the response and/or the re-growth of the sarcoma. The tumors from the same initial engraft in both the treated or untreated groups were individually processed, and the levels of certain cell cycle proteins were analyzed. Western blots for CDK4, cyclin D1, phosphor-pRb (at Ser807/811; at S780; at S795), CDK2, p21waf1, p16ink4a, phospho-p130 (at S762), phospho-p107 (at S975) and a-tubulin (loading control) are shown. The figure shows 3 representative untreated and treated tumors from the 5 models in which we observed re-growth of the treated sarcomas.

On the other hand, we did not observe a clear increase in $\mathrm{pRb}$ in tumors re-grown from treated tumors or an increase in $\mathrm{p} 16^{\mathrm{INK} 4 \mathrm{a}}$ protein, indicating that other mechanisms of resistance also exist. Interestingly, we detected an increase in $\mathrm{p} 21^{\text {wafl }}$ expression in tumors regrown from treated tumors compared to the corresponding untreated tumors (figure 7). At this point, do not know whether this increase is mechanistically shutting down the cell cycle and inducing delayed tumor growth or only accompanies the remaining tumor, which re-grows during the recovery period.

Therefore, it appears that palbociclib can be applied to other sarcoma types, especially those expressing high CDK4 levels and low p16 $6^{\text {INK4a }}$ levels. Similar data has been reported recently for dermatofibrosarcoma protuberans [46].
Increased CDK4 activity due to activating mutations, gene amplification, or the inhibition of CDK4inhibitory signals via the silencing of $\mathrm{p} 16^{\mathrm{INK} 4 \mathrm{a}}$ has been suggested as a tumor-initiating and/or tumor-promoting event in different tumor types. The amplification of CDK4, located on chromosome 12q13-14, has been reported in sarcomas, glioblastomas and breast cancers [66-69]. Activating CDK4 mutations have been reported in melanoma [70]. Both genomic events can lead to increased CDK4 signaling. Based on the accumulating evidence that CDK4 gene alterations are associated with the proliferation of different tumor types, CDK4 inhibitors are currently being studied in clinical trials.

Activating CDK4 mutations are less frequently reported in tumors than CDK4 gene amplification, and not 
reported in sarcoma tumors. Our data suggest that tumors carrying these mutants may not be suitable for treatment with palbociclib.

The amplification of chromosome 12q13-15 has been well documented in different sarcomas [66, 71-73]. Although it was originally thought that CDK4 is co-amplified with other Chr 12q13-15 genes, such as MDM2, it appears that different genes within this region are amplified dependent on the sarcoma subtype [74-76]. CDK4 gene amplification is commonly reported in atypical lipomatous tumors/well-differentiated liposarcomas, de-differentiated liposarcomas, and bone tumors. The overexpression of CDK4 was found to correspond to the gene amplification status and has been shown to be an especially useful marker for identifying well-differentiated and de-differentiated liposarcomas [77]. CDK4 amplification is correlated with a significantly poorer progression-free survival (PFS) and disease-free survival of liposarcoma [78]. Furthermore, in a small number of MPNSTs, or neurosarcomas, CDK4 gene amplification and subsequent increased CDK4 expression are significant predictors of poor patient survival [79].

Very little is known about whether genomic alterations in CDK4 can predict the tumor response to CDK inhibitors. Whereas the loss of $\mathrm{p} 16^{\text {ink4a }}$ function has been consistently associated with sensitivity to CDK inhibitors, at least in preclinical settings, the association of increased CDK4 activity with increased drug sensitivity remains unclear. No completed study has demonstrated that activating CDK4 mutations affect the sensitivity of tumors or tumor cells to CDK inhibitors independently of 12q13-15 amplification. Preclinical and clinical studies of liposarcoma suggested that the amplification of CDK4 may predict an increased response to CDK4 inhibitors [43, $44,80]$. However, CDK4 amplification or overexpression predicted either CDK inhibitor resistance or showed no association with the drug response in tumor models of glioblastoma and melanoma [81]. Our data support a positive role of high CDK4 levels in the response to CDK4 inhibitors. There are ongoing trials designed to test the utility of CDK4 genomic alterations in predicting the tumor response to CDK inhibitors. It should be noted that CDK inhibitors are not expected to be effective for tumors lacking $\mathrm{pRb}$ or overexpressing wild-type $\mathrm{p} 16^{\text {ink4a }}$ [61]. A phase II study demonstrated that the treatment of liposarcoma patients with palbociclib is associated with favorable PFS in tumors displaying $\mathrm{pRb}$ expression and CDK4 amplification [44]. Patients treated with palbociclib demonstrated $66 \%$ PFS, which significantly exceeded the primary study endpoint and included one partial response.

Alternatively, indirectly supporting the data suggesting CDK4 inhibition as suitable therapeutic strategy for sarcoma, in a phase 1 clinical trial, flavopiridol and doxorubicin combination therapy resulted in a disease control rate of $67 \%$ in progressive non-chemotherapyresponsive liposarcoma with likely CDK4 amplification
[80]. The majority of patients exhibited stable disease at 12 and 24 weeks $\left(\mathrm{PFS}_{12 \text { weeks }}\right.$ and $\left.\mathrm{PFS}_{24 \text { weeks }}\right)$, which is a favorable response rate in this patient population. In vivo sarcoma xenografts harboring CDK4 amplification also show significant responses to flavopiridol either as a single agent or in combination with doxorubicin.

In summary, our data support the efficacy of CDK4 inhibitors for sarcomas displaying increased CDK4 expression in general, particularly liposarcomas. Additionally, our results suggest that high levels of p16 ${ }^{\text {ink4a }}$ may indicate a poor effect of these drugs on the tumor. Additionally, we show that tumors harboring active mutant CDK $4{ }^{\mathrm{R} 24 \mathrm{C}}$ may respond poorly to palbociclib but may be suitable targets for other CDK4 inhibitors such as flavopiridol. Our data reinforce previously published data on the suitability of CDK4 inhibition for cell cycledependent tumors and support the performance of new molecularly directed clinical trials for other types of sarcoma.

\section{MATERIALS AND METHODS}

\section{Tumor samples}

Tumor tissues were obtained via the surgical resection of sarcomas performed at Virgen del Rocio Hospital (Seville, Spain). All patients provided written informed consent according to a protocol approved by the local ethics committee (CEI 2013/PI002). The experiments were performed according to the European guidelines for laboratory animal care. This study was approved by the IBIS Institutional Animal Care and Use Committee.

\section{PDX generation}

Sarcoma tissue samples were obtained from a single tumor area and were preserved in Dulbecco's modified Eagle's medium nutrient mixture/F10 (DMEM/F12; Sigma) containing 10\% fetal bovine serum, penicillin, streptomycin and Amphotericin B (100 mg/ml each; Sigma). The samples were maintained for less than 2 hours in cell culture medium at room temperature before implantation. Each tissue was divided into 2 parts. One part was frozen, and the remaining part was cut into small fragments of $2-3 \mathrm{~mm}$ in diameter and used for subcutaneous implantation into 6-week-old Foxn1nu athymic nude female mice (Harlan Laboratories, Netherlands). Upon reaching a size of $1,500 \mathrm{~mm} 3$, the mice were euthanized, and the tumors were re-grown in a similar fashion to perform the indicated experiments.

\section{In vivo treatments}

To initiate the experiments, each sample was xenografted into mice. Once the tumors reached 1500 
$\mathrm{mm} 3$, the tumors were harvested, cut into $2 \times 2 \times 2 \mathrm{~mm}$ blocks and implanted. The experiments were performed using cohorts of 6 animals. Mice were randomly allocated to the drug-treated and control-treated (solvent only) groups, and once the tumor grew to $20 \mathrm{~mm} 3$, the mice were treated for 3 weeks ( 5 days/eek). The mice were monitored daily for signs of distress and were weighed twice a week. The tumor size was measured using a caliper according to the following equation: tumor volume $=[$ length $\mathrm{x}$ width 2$] / 2$. The experiments were terminated when the tumor reached $1500 \mathrm{~mm} 3$. The drug (Palbociclib, PD0332991), was obtained from Pfizer, freshly prepared and orally administered. The concentration used in human is $125 \mathrm{mg} /$ dose. We have used higher doses in mice assuming a $70 \mathrm{Kg}$ average weight in humans. We have used $100 \mathrm{mg} / \mathrm{kg}$ in mice (equivalent to $2 \mathrm{mg} /$ dose approximately, averaging $25 \mathrm{gr}$ body weights each mice). This is equal or lower than the dose used in other xenograft studies but correspond to a 40 fold higher than the concentration used in humans. We have not found signs of toxicity.

\section{Western blot analyses}

Western blot analyses were performed as previously described $[50,51]$. Briefly, the cells were washed twice with PBS and lysed via sonication in lysis buffer (50 $\mathrm{mM}$ Tris-HCl, $\mathrm{pH}$ 7.5; 1\% NP-40; 1 mM Na3VO4; 150 $\mathrm{mM} \mathrm{NaCl} ; 20$ mM Na4P2O7; $100 \mathrm{mM} \mathrm{NaF} ; 1 \% \mathrm{Na}-$ deoxycholate; 0.1\% SDS; 1 mM EDTA; phosphatase inhibitor cocktail (Sigma) and protease inhibitor cocktail (Sigma)). The samples were separated on 6-15\% SDSPAGE gels, transferred to nitrocellulose membranes (Protran BA83, Whatman) and immunostained. The following primary antibodies and dilutions were used: Anti-p21 [C-19] 1:200 (Santa Cruz, \#sc-397), anti-p53 [FL-393] 1:200 (Santa Cruz, \#sc-6243), Anti-p16 (M156) 1:200 (Santa Cruz, \#sc-1207), anti-pRb 1:500 (BDPharmingen), anti-phospho-pRb (Ser807/811) 1:1000 (Cell Signaling), anti-phospho-histone H2A.X (Ser139) 1:1000 (Millipore 05-636) and monoclonal anti- $\alpha$-tubulin 1:1000 (Sigma 9026). Horseradish peroxidase-labeled rabbit anti-mouse (Amersham, diluted 1:3000) and goat anti-rabbit (Abcam, \#6721, diluted 1:3000) secondary antibodies were used. The proteins were visualized using an ECL detection system (Amersham Biosciences).

\section{Immunostaining and confocal analysis of 53BP1 foci}

Cells were seeded on glass cover slips and cultured for $16 \mathrm{~h}$. Then, $10 \mu \mathrm{M}$ palbociclib was added. After 48 $\mathrm{h}$, cover slips were fixed in $4 \%$ paraformaldehyde for $5 \mathrm{~min}$ at room temperature, washed twice with PBS, permeabilized in $0.5 \%$ Triton X-100 in PBS for 5 min and washed twice more with PBS. The samples were incubated in blocking solution (PBS containing 3\% bovine serum albumin) at $37^{\circ} \mathrm{C}$ for 1 hour, followed by incubation for 2 hours at room temperature in an anti-53BP1 antibody (Novus Biologicals, NB100-304) diluted 1:100. After washing with PBS, the cells were incubated in a speciesspecific Alexa 488-conjugated secondary antibody diluted 1:500 in blocking buffer for 1 hour at room temperature in the dark. The nuclei were counterstained with DAPI, and the slides were mounted using Prolong Gold Antifade reagent (Life Technologies). The samples were visualized under a confocal ultra-spectral microscope (Leica TCSSP2-AOBS-UV) via sequential scanning of the emission channels. The mean fluorescence intensity was measured for a minimum of 300 cells per condition using Leica confocal imaging software. The plotted values represent the means $( \pm \mathrm{SD})$ of each condition. Statistical significance was calculated using Student's $t$-test.

\section{Senescence-associated $B$-galactosidase activity}

Senescence-associated (SA) B-galactosidase (ß-Gal) activity was measured as previously described [52], except that the cells were incubated in 5-bromo-4chloro-3-indolyl-ß-D-galactopyranoside (XGal) at $\mathrm{pH} 5.5$ to increase the sensitivity of the assay. The percentage of cells expressing SA $\beta$-Gal was quantified by inspecting > 300 cells in each o three independent experiments.

\section{KI67 staining}

From each paraffin block, consecutive 5- $\mu \mathrm{m}$ tissue sections were cut, mounted, and dried on glass slides. The tissues were deparaffinized in xylol, followed by dehydration in graded alcohol solutions. Endogenous peroxidase activity was blocked using DAKO Blocking Solution (Agilent Technologies, United States) for 20 minutes at room temperature. Nonspecific protein binding was saturated using a phosphate-buffered saline (PBS) solution containing $10 \%$ fetal bovine serum, $1 \%$ bovine serum albumin and $0.3 \%$ Triton X-100 for 1 hour at room temperature. A mouse anti-human Ki-67 primary antibody (clone MIB-1; DAKO, Agilent technologies, United States) was used. The primary antibody was applied to tissue sections, and the slides were incubated overnight at $4^{\circ} \mathrm{C}$. A secondary antibody (Envision/HRI Dako SM 802) was applied for 1 hour at room temperature, and the immunocomplexes were revealed using Substrate Buffer SM 803 DAB and the chromogen DM 827 (ENVISION FLEX DAKO). The tissues were counterstained with hematoxylin (Dako), rehydrated in a graded alcohol series, and mounted using coverslips.

\section{Quantitative mRNA determination}

Total RNA was isolated via cell lysis in Qiazol reagent using an RNA Mini Kit (Qiagen, Inc.). First-strand cDNA synthesis was performed using $2.0 \mu \mathrm{g}$ of RNA, 
random primers, a dNTP mix and Multiscribe Reverse Transcriptase in a total volume of $50 \mu$ l (High Capacity Transcription Kit, Applied Biosystems). The series of conditions used for RT-PCR were as follows: $10 \mathrm{~min}$ at $25^{\circ} \mathrm{C}, 120 \mathrm{~min}$ at $37^{\circ} \mathrm{C}$, and $5 \mathrm{~min}$ at $95^{\circ} \mathrm{C}$.

To measure human $\mathrm{CDK} 4$, cyclin D1 and p16 expression, real-time PCR was performed using an ABI 7900HT PCR system (Applied Biosystems). The qPCR reactions were performed in 384-well plates via TaqMan Gene Expression Assays (Applied Biosystems). Gadph expression was examined as internal control. The relative mRNA quantities were expressed as 2-ßCt. Relative mRNA quantification and statistical analysis of qPCR data were conducted using RQ Manager 1.2.1 software (Applied Biosystems).

\section{Complementary RNA microarray assembly, hybridization, and analysis}

To investigate the transcriptional profiles of the samples, we used a GeneChip PrimeView and a Human Gene Expression Array GeneChip 3 IVT PLUS Reagent Kit (Affymetrix, USA). Total RNA (100 ng) was used for a reverse transcription reaction in the presence of a poly(A) binding proteins to generate gene expression profiles from mRNA. RNA amplification is based upon linear amplification and employs $\mathrm{T} 7$ in vitro transcription (IVT) technology. In the second step, single-stranded cDNA is converted to double-stranded cDNA, which acts as a template for in vitro transcription. The reaction uses DNA polymerase and RNase $\mathrm{H}$ to simultaneously degrade the RNA and synthesize second-strand cDNA. Labeled complementary RNA (cRNA) was synthesized and amplified via IVT of the second-stranded cDNA template using T7 RNA polymerase, followed by purification, fragmentation, and hybridization to the GeneChip PrimeView array. Hybridization was performed in the GeneChip Hybridization Oven 645 instrument at a temperature to $45^{\circ} \mathrm{C}$ with rotation at 60 RPM for 16 hours, followed by washing in the GeneChip Fluidics Station 450 and scanning using a laser scanner (GeneChip Scanner 3000 7G, Affymetrix). Finally, the data were collected using Expression Console software.

\section{Human primary sarcoma cell lines and culture conditions}

The sarcoma cell lines used in this study were previously characterized [53, 54]. The cells were maintained as a subconfluent monolayer in F-10 medium (Sigma) supplemented with $10 \%$ FBS, penicillinstreptomycin antibiotics (Sigma) and Fungizone (Amphotericin B, Sigma). Each cell line was cultured at $37^{\circ} \mathrm{C}$ and $95 \%$ humidity in $5 \% \mathrm{CO} 2$ under conditions of
$\mathrm{O} 2$ levels, culture medium and supplements indicated in the provider's instructions.

\section{Transfection}

Subconfluent AW and AX cells were transfected using the Lipofectamine method (Effectene, Qiagen) with $0.4 \mu \mathrm{g}$ of the empty mammalian expression plasmid pCMV6-neo or pCMV6-neo containing either the wild type CDK4 gene (Origene) or the R24C mutant CDK4 gene [55]. At 24 hours after transfection, the AW and AX cell lines were cultured in F-10 medium supplemented with $10 \%$ FBS and 0.8 $\mathrm{mg} / \mathrm{ml} \mathrm{G} 418$.

\section{Cytotoxicity assay}

Palbociclib was freshly prepared as a $30 \mathrm{mM}$ stock solution in sterilized deionized water for each experiment. Palbociclib was applied to a 96-well master plate at decreasing concentrations of $1 / 3$, such that $300 \mu \mathrm{M}$ was the highest concentration studied. The cell lines were seeded in 96-well plates (5,000-10,000 cells per well, depending on the cell size). At 24 hours after seeding, treatment was applied for 96 hours. Cell proliferation was determined by MTT assay and confirmed by crystal violet staining [56]. The IC50 was calculated using GraphPad Prism software.

\section{Apoptotic assay}

Cells were cultured for $16 \mathrm{~h}$, and then, $10 \mu \mathrm{M}$ palbociclib was added. Untreated cells were used as negative controls to define the basal level of apoptotic and necrotic or dead cells. After $48 \mathrm{~h}$, the cells were stained using the Annexin V-FITC apoptosis detection kit (Immunostep) according to the manufacturer's instructions. Briefly, the cells were washed in PBS and resuspended in Annexin-binding buffer, which included propidium iodide $(\mathrm{PI})$ at a concentration of $1 \times 10^{6}$ cells/ $\mathrm{ml}$. Then, Annexin V-FITC was added, and the cells were incubated for 15 minutes at room temperature $\left(25^{\circ} \mathrm{C}\right)$ in the dark. After incubation, $400 \mu \mathrm{l}$ of Annexin-binding buffer were added, and the cells were analyzed via flow cytometry within one hour using a BD FACS Canto II flow cytometer. The data were analyzed using BD FACS DIVA Software v 8.0.

\section{ACKNOWLEDGMENTS AND FUNDING}

The authors thank the donors and the Andalusian Public Health System Biobank (ISCIII-Red de Biobancos RD12/0036/0017) for the human specimens used in this study. Thanks to Pfizer for providing the palbociclib reagent used in this study. We also thank the Fundacion Oncologica FERO supported by Fundació Josep Botet. 
The AC lab was supported by grants to from the Spanish Ministry of Economy and Competitiveness, Plan Nacional de I+D+I 2008-2011, and Plan Estatal de I+D+I 20122016; ISCIII (Fis: PI12/00137, PI15/00045, RTICC: RD12/0036/0028), co-funded by FEDER from Regional Development European Funds (European Union), Consejeria de Ciencia e Innovacion (CTS-6844 and CTS1848) and Consejeria de Salud of the Junta de Andalucia (PI-0135-2010 and PI-0306-2012). This work has also been made possible thanks to the Plan Estatal de $\mathrm{I}+\mathrm{D}+\mathrm{i}$ 2013-2016 (Grant PIE13/0004) co-funded by the ISCIII and FEDER funds.

\section{CONFLICTS OF INTEREST}

Authors declare no conflicts of interest.

\section{REFERENCES}

1. Honoki K, Tsujiuchi T. Senescence bypass in mesenchymal stem cells: a potential pathogenesis and implications of pro-senescence therapy in sarcomas. Expert Rev Anticancer Ther. 2013; 13:983-996.

2. Helman LJ, Meltzer P. Mechanisms of sarcoma development. Nat Rev Cancer. 2003; 3:685-694.

3. Mackall CL, Meltzer PS, Helman LJ. Focus on sarcomas. Cancer Cell. 2002; 2:175-178.

4. Taylor BS, Barretina J, Maki RG, Antonescu CR, Singer S, Ladanyi M. Advances in sarcoma genomics and new therapeutic targets. Nat Rev Cancer. 2011; 11:541-557.

5. Jemal A, Siegel R, Xu J, Ward E. Cancer statistics, 2010. CA: a cancer journal for clinicians. 2010; 60:277-300.

6. Singer S, Demetri GD, Baldini EH, Fletcher CD. Management of soft-tissue sarcomas: an overview and update. Lancet Oncol. 2000; 1:75-85.

7. Svancarova L, Blay JY, Judson IR, van Hoesel QG, van Oosterom AT, le Cesne A, Keizer HJ, Hermans C, van Glabbeke M, Verweij J, Hogendoorn PC, Nielsen OS. Gemcitabine in advanced adult soft-tissue sarcomas. A phase II study of the EORTC Soft Tissue and Bone Sarcoma Group. Eur J Cancer. 2002; 38:556-559.

8. Nielsen OS, Judson I, van Hoesel Q, le Cesne A, Keizer HJ, Blay JY, van Oosterom A, Radford JA, Svancarova L, Krzemienlecki K, Hermans C, van Glabbeke M, Oosterhuis JW, Verweij J. Effect of high-dose ifosfamide in advanced soft tissue sarcomas. A multicentre phase II study of the EORTC Soft Tissue and Bone Sarcoma Group. Eur J Cancer. 2000; 36:61-67.

9. Izbicka E, Lawrence R, Raymond E, Eckhardt G, Faircloth G, Jimeno J, Clark G, Von Hoff DD. In vitro antitumor activity of the novel marine agent, ecteinascidin-743 (ET-743, NSC-648766) against human tumors explanted from patients. Ann Oncol. 1998; 9:981-987.
10. Le Cesne A, Blay JY, Judson I, Van Oosterom A, Verweij J, Radford J, Lorigan P, Rodenhuis S, Ray-Coquard I, Bonvalot S, Collin F, Jimeno J, Di Paola E, Van Glabbeke M, Nielsen OS. Phase II study of ET-743 in advanced soft tissue sarcomas: a European Organisation for the Research and Treatment of Cancer (EORTC) soft tissue and bone sarcoma group trial. J Clin Oncol. 2005; 23:576-584.

11. Hanahan D, Weinberg RA. The hallmarks of cancer. Cell. 2000; 100:57-70.

12. Hanahan D, Weinberg RA. Hallmarks of cancer: the next generation. Cell. 2011; 144:646-674.

13. Gil J, Peters G. Regulation of the INK4b-ARF-INK4a tumour suppressor locus: all for one or one for all. Nat Rev Mol Cell Biol. 2006; 7:667-677.

14. Malumbres M, Barbacid M. Cell cycle kinases in cancer. Curr Opin Genet Dev. 2007; 17:60-65.

15. Sabah M, Cummins R, Leader M, Kay E. Aberrant expression of the $\mathrm{Rb}$ pathway proteins in soft tissue sarcomas. Applied immunohistochemistry \& molecular morphology : AIMM / official publication of the Society for Applied Immunohistochemistry. 2006; 14:397-403.

16. Puyol M, Martin A, Dubus P, Mulero F, Pizcueta P, Khan G, Guerra C, Santamaria D, Barbacid M. A synthetic lethal interaction between K-Ras oncogenes and Cdk4 unveils a therapeutic strategy for non-small cell lung carcinoma. Cancer Cell. 2010; 18:63-73.

17. Drosten M, Dhawahir A, Sum EY, Urosevic J, Lechuga CG, Esteban LM, Castellano E, Guerra C, Santos E, Barbacid M. Genetic analysis of Ras signalling pathways in cell proliferation, migration and survival. EMBO J. 2010; 29:1091-1104.

18. Yu Q, Sicinska E, Geng Y, Ahnstrom M, Zagozdzon A, Kong Y, Gardner H, Kiyokawa H, Harris LN, Stal O, Sicinski P. Requirement for CDK4 kinase function in breast cancer. Cancer Cell. 2006; 9:23-32.

19. Robles AI, Rodriguez-Puebla ML, Glick AB, Trempus C, Hansen L, Sicinski P, Tennant RW, Weinberg RA, Yuspa SH, Conti CJ. Reduced skin tumor development in cyclin D1-deficient mice highlights the oncogenic ras pathway in vivo. Genes Dev. 1998; 12:2469-2474.

20. Tetsu O, McCormick F. Proliferation of cancer cells despite CDK2 inhibition. Cancer Cell. 2003; 3:233-245.

21. Miliani de Marval PL, Macias E, Rounbehler R, Sicinski P, Kiyokawa H, Johnson DG, Conti CJ, RodriguezPuebla ML. Lack of cyclin-dependent kinase 4 inhibits c-myc tumorigenic activities in epithelial tissues. Mol Cell Biol. 2004; 24:7538-7547.

22. Malumbres M, Sotillo R, Santamaria D, Galan J, Cerezo A, Ortega S, Dubus P, Barbacid M. Mammalian cells cycle without the D-type cyclin-dependent kinases Cdk4 and Cdk6. Cell. 2004; 118:493-504.

23. Santamaria D, Barriere C, Cerqueira A, Hunt S, Tardy C, Newton K, Caceres JF, Dubus P, Malumbres M, 
Barbacid M. Cdk1 is sufficient to drive the mammalian cell cycle. Nature. 2007; 448:811-815.

24. Landis MW, Pawlyk BS, Li T, Sicinski P, Hinds PW. Cyclin D1-dependent kinase activity in murine development and mammary tumorigenesis. Cancer Cell. 2006; 9:13-22.

25. Yu Q, Geng Y, Sicinski P. Specific protection against breast cancers by cyclin D1 ablation. Nature. 2001; 411:1017-1021.

26. Rodriguez-Puebla ML, Miliani de Marval PL, LaCava M, Moons DS, Kiyokawa H, Conti CJ. Cdk4 deficiency inhibits skin tumor development but does not affect normal keratinocyte proliferation. Am J Pathol. 2002; 161:405-411.

27. Knudsen ES, Wang JY. Targeting the RB-pathway in cancer therapy. Clin Cancer Res. 2010; 16:1094-1099.

28. Franco J, Witkiewicz AK, Knudsen ES. CDK4/6 inhibitors have potent activity in combination with pathway selective therapeutic agents in models of pancreatic cancer. Oncotarget. 2014; 5:6512-6525.

29. Kennedy AL, Vallurupalli M, Chen L, Crompton B, Cowley G, Vazquez F, Weir BA, Tsherniak A, Parasuraman S, Kim S, Alexe G, Stegmaier K. Functional, chemical genomic, and super-enhancer screening identify sensitivity to cyclin D1/CDK4 pathway inhibition in Ewing sarcoma. Oncotarget. 2015;

30. Gallorini M, Cataldi A, di Giacomo V. Cyclin-dependent kinase modulators and cancer therapy. BioDrugs : clinical immunotherapeutics, biopharmaceuticals and gene therapy. 2012; 26:377-391.

31. Dickson MA. Molecular pathways: CDK4 inhibitors for cancer therapy. Clin Cancer Res. 2014; 20:3379-3383.

32. Carnero A. Targeting the cell cycle for cancer therapy. Br J Cancer. 2002; 87:129-133.

33. Sotillo R, Renner O, Dubus P, Ruiz-Cabello J, MartinCaballero J, Barbacid M, Carnero A, Malumbres M. Cooperation between Cdk4 and p27kip1 in tumor development: a preclinical model to evaluate cell cycle inhibitors with therapeutic activity. Cancer Res. 2005; 65:3846-3852.

34. Shapiro GI. Cyclin-dependent kinase pathways as targets for cancer treatment. J Clin Oncol. 2006; 24:1770-1783.

35. Kovatcheva M, Liu DD, Dickson MA, Klein ME, O'Connor R, Wilder FO, Socci ND, Tap WD, Schwartz GK, Singer S, Crago AM, Koff A. MDM2 turnover and expression of ATRX determine the choice between quiescence and senescence in response to CDK4 inhibition. Oncotarget. 2015; 6:8226-8243.

36. Sausville EA. Cyclin-dependent kinase modulators studied at the NCI: pre-clinical and clinical studies. Curr Med Chem Anticancer Agents. 2003; 3:47-56.

37. Senderowicz AM. Development of cyclin-dependent kinase modulators as novel therapeutic approaches for hematological malignancies. Leukemia. 2001; 15:1-9.

38. Bose P, Simmons GL, Grant S. Cyclin-dependent kinase inhibitor therapy for hematologic malignancies. Expert Opin Investig Drugs. 2013; 22:723-738.
39. Logan JE, Mostofizadeh N, Desai AJ, VONE E, Conklin D, Konkankit V, Hamidi H, Eckardt M, Anderson L, Chen HW, Ginther C, Taschereau E, Bui PH, Christensen JG, Belldegrun AS, Slamon DJ, et al. PD0332991, a potent and selective inhibitor of cyclin-dependent kinase $4 / 6$, demonstrates inhibition of proliferation in renal cell carcinoma at nanomolar concentrations and molecular markers predict for sensitivity. Anticancer Res. 2013; 33:2997-3004.

40. Finn RS, Dering J, Conklin D, Kalous O, Cohen DJ, Desai AJ, Ginther C, Atefi M, Chen I, Fowst C, Los G, Slamon DJ. PD 0332991, a selective cyclin D kinase 4/6 inhibitor, preferentially inhibits proliferation of luminal estrogen receptor-positive human breast cancer cell lines in vitro. Breast Cancer Res. 2009; 11:R77.

41. Fry DW, Harvey PJ, Keller PR, Elliott WL, Meade M, Trachet E, Albassam M, Zheng X, Leopold WR, Pryer NK, Toogood PL. Specific inhibition of cyclin-dependent kinase 4/6 by PD 0332991 and associated antitumor activity in human tumor xenografts. Mol Cancer Ther. 2004; 3:1427-1438.

42. Saab R, Bills JL, Miceli AP, Anderson CM, Khoury JD, Fry DW, Navid F, Houghton PJ, Skapek SX. Pharmacologic inhibition of cyclin-dependent kinase 4/6 activity arrests proliferation in myoblasts and rhabdomyosarcoma-derived cells. Mol Cancer Ther. 2006; 5:1299-1308.

43. Zhang YX, Sicinska E, Czaplinski JT, Remillard SP, Moss S, Wang Y, Brain C, Loo A, Snyder EL, Demetri GD, Kim S, Kung AL, Wagner AJ. Antiproliferative effects of CDK4/6 inhibition in CDK4-amplified human liposarcoma in vitro and in vivo. Mol Cancer Ther. 2014; 13:2184-2193.

44. Dickson MA, Tap WD, Keohan ML, D'Angelo SP, Gounder MM, Antonescu CR, Landa J, Qin LX, Rathbone DD, Condy MM, Ustoyev Y, Crago AM, Singer S, Schwartz GK. Phase II trial of the CDK4 inhibitor PD0332991 in patients with advanced CDK4-amplified well-differentiated or dedifferentiated liposarcoma. J Clin Oncol. 2013; 31:2024-2028.

45. Wiedemeyer WR, Dunn IF, Quayle SN, Zhang J, Chheda MG, Dunn GP, Zhuang L, Rosenbluh J, Chen S, Xiao Y, Shapiro GI, Hahn WC, Chin L. Pattern of retinoblastoma pathway inactivation dictates response to CDK4/6 inhibition in GBM. Proc Natl Acad Sci U S A. 2010; 107:11501-11506.

46. Eilers G, Czaplinski JT, Mayeda M, Bahri N, Tao D, Zhu M, Hornick JL, Lindeman NI, Sicinska E, Wagner AJ, Fletcher JA, Marino-Enriquez A. CDKN2A/p16 loss implicates CDK4 as a therapeutic target in imatinib-resistant dermatofibrosarcoma protuberans. Mol Cancer Ther. 2015; .

47. Malumbres M, Barbacid M. Is Cyclin D1-CDK4 kinase a bona fide cancer target?. Cancer Cell. 2006; 9:2-4.

48. Rocca A, Farolfi A, Bravaccini S, Schirone A, Amadori D. Palbociclib (PD 0332991) : targeting the cell cycle machinery in breast cancer. Expert Opin Pharmacother. 2014; 15:407-420. 
49. Collins I, Garrett MD. Targeting the cell division cycle in cancer: $\mathrm{CDK}$ and cell cycle checkpoint kinase inhibitors. Curr Opin Pharmacol. 2005; 5:366-373.

50. Carnero A, Beach DH. Absence of p21WAF1 cooperates with c-myc in bypassing Ras-induced senescence and enhances oncogenic cooperation. Oncogene. 2004; 23:6006-6011.

51. Castro ME, Ferrer I, Cascon A, Guijarro MV, Lleonart M, Cajal SR, Leal JF, Robledo M, Carnero A. PPP1CA contributes to the senescence program induced by oncogenic Ras. Carcinogenesis. 2008; 29:491-499.

52. Ruiz L, Traskine M, Ferrer I, Castro E, Leal JF, Kaufman M, Carnero A. Characterization of the p53 response to oncogene-induced senescence. PLoS ONE. 2008; 3:e3230.

53. Moneo V, Serelde BG, Fominaya J, Leal JF, BlancoAparicio C, Romero L, Sanchez-Beato M, Cigudosa JC, Tercero JC, Piris MA, Jimeno J, Carnero A. Extreme sensitivity to Yondelis (Trabectedin, ET-743) in low passaged sarcoma cell lines correlates with mutated p53. J Cell Biochem. 2007; 100:339-348.

54. Moneo V, Serelde BG, Leal JF, Blanco-Aparicio C, DiazUriarte R, Aracil M, Tercero JC, Jimeno J, Carnero A. Levels of p27(kip1) determine Aplidin sensitivity. Mol Cancer Ther. 2007; 6:1310-1316.

55. Quereda V, Martinalbo J, Dubus P, Carnero A, Malumbres M. Genetic cooperation between p21Cip1 and INK4 inhibitors in cellular senescence and tumor suppression. Oncogene. 2007; 26:7665-7674.

56. Leal JF, Ferrer I, Blanco-Aparicio C, HernandezLosa J, Ramon YCS, Carnero A, Lleonart ME. S-adenosylhomocysteine hydrolase downregulation contributes to tumorigenesis. Carcinogenesis. 2008; 29:2089-2095.

57. Moneo V, Serelde BG, Blanco-Aparicio C, Diaz-Uriarte R, Aviles P, Santamaria G, Tercero JC, Cuevas C, Carnero A. Levels of active tyrosine kinase receptor determine the tumor response to Zalypsis. BMC Cancer. 2014; 14:281.

58. Sutherland RL, Musgrove EA. CDK inhibitors as potential breast cancer therapeutics: new evidence for enhanced efficacy in ER+ disease. Breast Cancer Res. 2009; 11:112.

59. Morikawa A, Henry NL. Palbociclib for the Treatment of Estrogen Receptor-Positive, HER2-Negative Metastatic Breast Cancer. Clin Cancer Res. 2015; .

60. Dickson MA. Systemic treatment options for radiationassociated sarcomas. Curr Treat Options Oncol. 2014; 15:476-481.

61. Guha M. Cyclin-dependent kinase inhibitors move into Phase III. Nat Rev Drug Discov. 2012; 11:892-894.

62. Serrano M, Gomez-Lahoz E, DePinho RA, Beach D, BarSagi D. Inhibition of ras-induced proliferation and cellular transformation by p16INK4. Science. 1995; 267:249-252.

63. Carnero A, Hannon GJ. The INK4 family of CDK inhibitors. Curr Top Microbiol Immunol. 1998; 227:43-55.
64. Ambrosini G, Cheema HS, Seelman S, Teed A, Sambol EB, Singer S, Schwartz GK. Sorafenib inhibits growth and mitogen-activated protein kinase signaling in malignant peripheral nerve sheath cells. Mol Cancer Ther. 2008; 7:890-896.

65. Sun P, Dong P, Dai K, Hannon GJ, Beach D. p53-independent role of MDM2 in TGF-beta1 resistance. Science. 1998; 282:2270-2272.

66. Khatib ZA, Matsushime H, Valentine M, Shapiro DN, Sherr CJ, Look AT. Coamplification of the CDK4 gene with MDM2 and GLI in human sarcomas. Cancer Res. 1993; 53:5535-5541.

67. Collins VP. Gene amplification in human gliomas. Glia. 1995; 15:289-296.

68. Reifenberger G, Reifenberger J, Ichimura K, Meltzer PS, Collins VP. Amplification of multiple genes from chromosomal region 12q13-14 in human malignant gliomas: preliminary mapping of the amplicons shows preferential involvement of CDK4, SAS, and MDM2. Cancer Res. 1994; 54:4299-4303.

69. An HX, Beckmann MW, Reifenberger G, Bender HG, Niederacher D. Gene amplification and overexpression of CDK4 in sporadic breast carcinomas is associated with high tumor cell proliferation. Am J Pathol. 1999; 154:113-118.

70. Wolfel T, Hauer M, Schneider J, Serrano M, Wolfel C, Klehmann-Hieb E, De Plaen E, Hankeln T, Meyer zum Buschenfelde KH, Beach D. A p16INK4a-insensitive CDK4 mutant targeted by cytolytic $\mathrm{T}$ lymphocytes in a human melanoma. Science. 1995; 269:1281-1284.

71. Dal Cin P, Kools P, De Jonge I, Moerman P, Van de Ven W, Van den Berghe H. Rearrangement of 12q14-15 in pulmonary chondroid hamartoma. Genes Chromosomes Cancer. 1993; 8:131-133.

72. Pedeutour F, Suijkerbuijk RF, Van Gaal J, Van de Klundert W, Coindre JM, Van Haelst A, Collin F, Huffermann K, Turc-Carel C. Chromosome 12 origin in rings and giant markers in well-differentiated liposarcoma. Cancer Genet Cytogenet. 1993; 66:133-134.

73. Pedeutour F, Merscher S, Durieux E, Montgomery K, Krauter K, Clevy JP, Barcelo G, Kucherlapati R, Gaudray P, Turc-Carel C. Mapping of the 12q12-q22 region with respect to tumor translocation breakpoints. Genomics. 1994; 22:512-518.

74. Kanoe H, Nakayama $T$, Murakami H, Hosaka $T$, Yamamoto H, Nakashima Y, Tsuboyama T, Nakamura T, Sasaki MS, Toguchida J. Amplification of the CDK4 gene in sarcomas: tumor specificity and relationship with the RB gene mutation. Anticancer Res. 1998; 18:2317-2321.

75. Shimada $\mathrm{S}$, Ishizawa $\mathrm{T}$, Ishizawa $\mathrm{K}$, Matsumura $\mathrm{T}$, Hasegawa T, Hirose T. The value of MDM2 and CDK4 amplification levels using real-time polymerase chain reaction for the differential diagnosis of liposarcomas and their histologic mimickers. Hum Pathol. 2006; 37:1123-1129.

76. Mejia-Guerrero S, Quejada M, Gokgoz N, Gill M, Parkes RK, Wunder JS, Andrulis IL. Characterization of the 12q15 
MDM2 and 12q13-14 CDK4 amplicons and clinical correlations in osteosarcoma. Genes Chromosomes Cancer. 2010; 49:518-525.

77. Binh MB, Sastre-Garau X, Guillou L, de Pinieux G, Terrier P, Lagace R, Aurias A, Hostein I, Coindre JM. MDM2 and CDK4 immunostainings are useful adjuncts in diagnosing well-differentiated and dedifferentiated liposarcoma subtypes: a comparative analysis of 559 soft tissue neoplasms with genetic data. The American journal of surgical pathology. 2005; 29:1340-1347.

78. Lee SE, Kim YJ, Kwon MJ, Choi DI, Lee J, Cho J, Seo SW, Kim SJ, Shin YK, Choi YL. High level of CDK4 amplification is a poor prognostic factor in well-differentiated and dedifferentiated liposarcoma. Histol Histopathol. 2014; 29:127-138.
79. Yu Z, Kelsey A, Alaggio R, Parham D. Clinical utility gene card for: Alveolar rhabdomyosarcoma. European journal of human genetics : EJHG. 2012; 20.

80. Luke JJ, D'Adamo DR, Dickson MA, Keohan ML, Carvajal RD, Maki RG, de Stanchina E, Musi E, Singer S, Schwartz GK. The cyclin-dependent kinase inhibitor flavopiridol potentiates doxorubicin efficacy in advanced sarcomas: preclinical investigations and results of a phase I dose-escalation clinical trial. Clin Cancer Res. 2012; 18:2638-2647.

81. Cen L, Carlson BL, Schroeder MA, Ostrem JL, Kitange GJ, Mladek AC, Fink SR, Decker PA, Wu W, Kim JS, Waldman T, Jenkins RB, Sarkaria JN. p16-Cdk4-Rb axis controls sensitivity to a cyclin-dependent kinase inhibitor PD0332991 in glioblastoma xenograft cells. Neuro Oncol. 2012; 14:870-881. 